\title{
The Significance of Microbial Transformation of Nitrogen Compounds in the Light of Integrated Crop Management
}

\author{
Aleksandra Grzyb, Agnieszka Wolna-Maruwka *(D) and Alicja Niewiadomska \\ Department of General and Environmental Microbiology, Poznań University of Life Sciences, Szydłowska 50, \\ 60-656 Poznań, Poland; aleksandra.grzyb@up.poznan.pl (A.G.); alicja.niewiadomska@up.poznan.pl (A.N.) \\ * Correspondence: amaruwka@up.poznan.pl; Tel.: +48-618466724
}

check for updates

Citation: Grzyb, A.;

Wolna-Maruwka, A.; Niewiadomska,

A. The Significance of Microbial

Transformation of Nitrogen

Compounds in the Light of Integrated

Crop Management. Agronomy 2021,

11, 1415. https://doi.org/10.3390/

agronomy11071415

Academic Editors: Anna Gałązka

Agnieszka Wolińska and Vanessa

Alvarez Lopez

Received: 18 June 2021

Accepted: 13 July 2021

Published: 15 July 2021

Publisher's Note: MDPI stays neutral with regard to jurisdictional claims in published maps and institutional affiliations.

Copyright: (c) 2021 by the authors. Licensee MDPI, Basel, Switzerland. This article is an open access article distributed under the terms and conditions of the Creative Commons Attribution (CC BY) license (https:// creativecommons.org/licenses/by/ $4.0 /)$.

\begin{abstract}
Nitrogen $(\mathrm{N})$ is widely distributed in the lithosphere, hydrosphere, atmosphere and biosphere. It is a basic component of every plant cell as well as microorganisms, as a component of proteins, nucleic acids and chlorophyll. It enters soil with organic and mineral fertilizers, plant and animal residues and biological nitrogen fixation. There are various forms of nitrogen in soil, and this element is usually transformed by microorganisms. The transformation of nitrogen compounds (ammonification, nitrification and immobilization) is significantly influenced by climatic conditions and the physicochemical properties of soil. Microbial mineralization of nitrogen organic matter results in the enrichment of soil with this element, which is necessary to generate a yield. The amount of nitrogen entering soil through the mineralization of crop residues ranges from 15 to $45 \mathrm{~kg} \mathrm{~N} / \mathrm{ha}$ in cereal residues and from 80 to $144 \mathrm{~kg} \mathrm{~N} /$ ha in winter rape residues. Biological nitrogen fixation can increase the nitrogen content in soil by $30-50 \mathrm{~kg} / \mathrm{ha} /$ year. In recent decades, the mismanagement of mineral fertilizers has drastically changed the natural balance of the nitrogen cycle. Every year huge amounts of nitrogen compounds enter the aquatic ecosystems and cause their eutrophication. That is why it is important to have adequate knowledge of sustainable fertilization so as to practice integrated crop management.
\end{abstract}

Keywords: nitrogencycle; crop management; fertilization; soil microorganisms; nitrogen transformations; crop residues; crop yield

\section{Introduction}

In the natural environment, nitrogen is distributed between the atmosphere, soil and the biomass of microorganisms. The total content of nitrogen in mineral soils usually ranges from $0.02 \%$ to $0.3 \%$, which corresponds to about $600-9000 \mathrm{~kg} \mathrm{~N} / \mathrm{ha}$ in the arable layer. Only a small part of the total nitrogen content in soil, i.e., less than $5 \%$, is directly available to plants [1]. The largest amount of this element in mineral soils can be found at humus horizons. Then, the content decreases rapidly at deeper layers in the soil profile. Generally, in arable soils, about $90 \%$ of nitrogen is combined with organic matter in the form of amino acids (about 60\%), amino sugars (5-15\%), amide nitrogen (up to 15\%) and non-hydrolyzing nitrogen (up to $30 \%$ ). The remaining $10 \%$ of the nitrogen content is in mineral forms [2,3]. Dinitrogen is a gas that makes up 79\% of the Earth's atmosphere, and it is definitely the most abundant form of nitrogen in the biosphere. However, most organisms, including plants, cannot absorb nitrogen in this form. It can be absorbed only after soil microorganisms have transformed it into $\mathrm{NH}_{3}$ [4].

Nitrogen is a basic element of every living cell because it is a component of nucleic acids (DNA, RNA), proteins, membrane lipids, ATP, NADH, NADPH and photosynthetic pigments. According to Kopcewicz et al. [5] and Zboinska [6], it is also a component of acyl residues (coenzyme A), cytochromes, cytokinins and some vitamins, as well as secondary plant metabolites, such as alkaloids, betalains, mustard oils and cyanogenic glycosides. 
Nitrogen enters soil through mineral and organic fertilization (manure, crop residues) and as a result of biological fixation of elemental nitrogen by symbiotic and free-living bacteria [7,8]. Plants absorb two forms of nitrogen: ammonium $\left(\mathrm{NH}_{4}{ }^{+}\right)$and nitrate $\left(\mathrm{NO}_{3}{ }^{-}\right)$. The uptake additionally depends on the plant's phase of development and temperature. At early phases of development and lower temperatures, plants mainly take up ammonium nitrogen. In acidic soils, the nitrate form is better absorbed, whereas in neutral soils, the ammonium form. No other element that is necessary for life has so many forms in soil as nitrogen and is transformed by microorganisms [9]. According to Lamb et al. [10], the circulation of nitrogen in the environment involves six microbiological processes, i.e., atmospheric nitrogen fixation, mineralization, immobilization, nitrification, denitrification and anaerobic ammonium oxidation (anammox), which are significantly influenced by the physicochemical properties of soil and climatic conditions. Soil microorganisms are very sensitive to changes in environmental conditions, such as the soil water content and $\mathrm{pH}$, temperature, plant cover type and soil type, and their activity also depends on agricultural management practices [11-13].

Microorganisms play a key role in the nitrogen transformation cycle because they have genes encoding enzymes involved in nitrogen metabolism, which are used as indicators of the potential of this cycle [14]. The following microbial marker genes influencing the rate of transformation of nitrogen compounds have been studied most frequently: nifH (encoding nitrogenase reductase), amo $A$ (encoding ammonia monooxygenase), nirK and nirS (encoding nitrite reductase) and nosZ (encoding nitrous oxide reductase) [15-17]. According to Levy-Booth [18], the characterization of functional genes involved in the biogeochemical cycle of nitrogen helps to relate groups of microorganisms directly to the processes of transformation of this element. According to Geisseler et al. [19], the understanding of microbial nitrogen transformations is necessary to find the right nitrogen management methods and understand their influence on the productivity of the ecosystem.

As plants have a very high demand for nitrogen, the availability of this element is often the main factor limiting their growth and development. Therefore, every year more than 110 million tons of nitrogen is applied to farmlands around the world, including 15 million tons in Europe. Globally, wheat and maize consume 32\%, whereas oil plants consume $10 \%$ of nitrogen. The annual nitrogen consumption in Poland is $70 \mathrm{~kg} / \mathrm{ha}$, which results in a grain yield of $4.2 \mathrm{t} / \mathrm{ha}$ [20-23].

An improper balance of nutrients may have negative effects on plants because neither nitrogen deficiency nor its excess is good for them. An insufficient supply of nitrogen results in the stunted growth of plants, which are poorly branched and have a low root-toshoot ratio. Their leaves are small and thin, with signs of chlorosis. The first symptoms of nitrogen deficiency appear on older leaves, and they gradually spread to higher leaves on the shoot. Moreover, a nitrogen deficiency results in fewer flowering shoots (spikes), limited setting of flower buds, as well as faster flowering, which results in fewer flowers (caryopses per spike). Consequently, there is lower seed weight, lower protein content in seeds and lower useful yield. An excess of nitrogen also negatively affects the yield and quality of crops. Excessive fertilization causes delayed and irregular flowering of plants. Shoots are thick and end their growth late, which delays the harvest time. Leaves are large, thick, dark green and susceptible to many fungal diseases, and they are willingly inhabited by pests. Cereals, maize and rape are susceptible to lodging. Excessive nitrogen fertilization of rape results in an overgrowth of vegetative organs, such as stems and leaves, and a decrease in the number of generative organs, i.e., siliquae. Additionally, excessive nitrogen fertilization of winter rape in autumn reduces its winter hardiness. Too high doses of nitrogen stimulate the rapid growth and development of new organs in plants. The process involves the consumption of sugars, which should be stored for winter. In consequence, rape plants are poorly hardened, straggling and overhydrated, which increases their sensitivity to frost. Nitrogen excess also contributes to the accumulation of harmful nitrates in root vegetables (carrot, beet, radish, celery, etc.) and leafy vegetables (lettuce, cabbage, spinach, parsley, etc.). Extremely high amounts of nitrogen fertilizer 
cause the tips of shoots and the youngest leaves to dry up. In consequence, the useful yield of crops decreases [24-28].

The natural nitrogen cycle is disturbed by anthropogenic factors, such as the use of nitrogenous mineral fertilizers, the combustion of fossil fuels, and the release of nitrogen into waters as a result of their contamination with sewage [29]. Large amounts of nitrogen fertilizers applied in farmlands influence the processes of transformation of nitrogen compounds in soil, especially nitrification and denitrification. This results in increased $\mathrm{N}_{2} \mathrm{O}$ production, the leaching of nitrates from fields and groundwater contamination [30]. Large amounts of nitrogen used in agricultural and urban areas end up in rivers. This may cause hypoxia or anoxia (lack of oxygen), changes in the biodiversity of waterbodies, changes in the food web structure, and overall habitat degradation [31]. One of the common consequences of increased amounts of nitrogen in soil as a result of poor management of mineral fertilization is the increase in harmful algae blooms due to the high mortality of fish and shellfish in waterbodies [32,33]. According to Johnson et al. [34], changes in the nitrogen cycle increase the risk of diseases (methemoglobinemia, enteritis and respiratory failure) in humans and wild animals. In order to avoid these consequences, integrated crop management has been introduced. The purpose of this system is to obtain highquality crops without a negative influence on the environment and the health of humans and animals.

The aim of this work is to systematize the knowledge on nitrogen transformations in soil while showing the importance of microorganisms in the entire process, with particular emphasis on the integrated pest management program. The brief and careful presentation of information on microbiological transformations of $\mathrm{N}$ compounds in the paper resulted from the need to understand the mechanisms of their operation in providing plants with a source of nitrogen against the background of an innovative approach to plant cultivation.

\section{Nitrogen Fertilization vs. Yield Potential}

Fertilization is an essential agricultural practice to maximize yield and increase soil fertility. The fertilizer market includes mineral fertilizers (e.g., ammonium nitrate and ammonium chloride), organic ones (crop residues, animal excrements) and also organochemical (urea). According to Blanco-Canqui and Schlegel [35] and Wang et al. [36], the efficiency of mineral fertilization is low, and excessive amounts of mineral fertilizers may seriously degrade soil and pollute the environment. Han et al. [37], Li et al. [38], Stockmann et al. [39], Xiang et al. [40], Zamanian and Kuzyakov [41] and Zhou et al. [42] proved that long-term mineral fertilization contributes to soil acidification due to the formation of protons when ammonium becomes oxidized into nitrites and nitrates. Apart from that, it adversely affects the processes of nitrification, denitrification and fixation of atmospheric nitrogen and reduces the pool of organic carbon in soil. Mineral fertilizers also reduce the diversity of bacteria and fungi as well as soil microbial biomass [43-46]. Hallin et al. [47] and Wessén et al. [48] observed a significant decrease in the count of bacteria and archaea in the soil fertilized with ammonium sulfate. Treseder [49] found that fertilization with mineral nitrogen reduced the microbial biomass by $15 \%$ on average. The study by Paungfoo-Lonhienne et al. [50] showed that mineral fertilization increased the count of fungal pathogens as a result of soil acidification. Morrison et al. [51] observed that the difference in the content of plant pathogens between the control (unfertilized) variant and the one where mineral fertilization had been applied was greater than $2 \%$. Afreh et al. [52], Miller et al. [53], Saunders et al. [54] and Zhang et al. [55] concluded that the soil environment should be protected from the negative effects of mineral fertilization with organic fertilizers, which increase the soil $\mathrm{pH}$, prevent soil acidification and have a positive effect on the count, diversity and activity of microorganisms. Xiang et al. [56] observed that the long-term use of manure increased the abundance of some bacterial species, e.g., Pseudaleuria and Hypocreales, which exhibited antagonism against plant pathogens, and thus, they improved the growth and development of plants. Bandyopadhyay et al. [57], Herencia et al. [58] and Miller [53] proved that organic fertilizers increased the pool of organic 
carbon in soil and its hydraulic conductivity while reducing its bulk density. Šimon [59] observed that fertilization with manure increased the mean content of total nitrogen in the soil by $9.1 \%$, whereas mineral fertilization (NPK) increased it by $8.0 \%$ in comparison with the unfertilized (control) variant. According to Fließbach et al. [60], in order to ensure the sustainability of agricultural production, it is essential to maintain the right soil quality, which can be assessed with various biological, physical and chemical indicators that are sensitive to changes in nitrogen management and related to key soil functions. Therefore, it is very important to follow the principles of integrated crop management, which includes balanced fertilization. Integrated crop management (ICM) is a modern food production system that uses technological and biological progress in cultivation, crop protection and fertilization in a sustainable manner while paying particular attention to environmental protection and human health [61]. The system enables the production of healthy food of plant origin, which does not contain excessive amounts of residues of crop protection products, heavy metals, nitrates, other elements and harmful substances. Nitrogen management in Poland is subject to the Regulation of the Minister of Agriculture and Rural Development on Integrated Agricultural Production of 16 December 2010 [62]. Apart from that, the safety of fertilization in the European Union is laid down in Regulation (EU) 2019/1009 of the European Parliament and the Council of 5 June 2019 [63], which includes provisions on making fertilizing products available on the market. In Poland, it is regulated by the Fertilizer and Fertilization Act of 10 July 2007 [64].

According to Delgado and Lemunyon [65], the proper management of fertilizer components is the knowledge and practical skill that directly connects factors such as soil, crops and weather conditions with cultivation and irrigation practices to optimize the use of these components by plants and limit the dispersion of the components that may negatively affect the environment. According to Prasad et al. [66] and Shober et al. [67], integrated agriculture is based on conscious fertilizer management processes, which aim to precisely determine the source of nitrogen in soil and the extent of its uptake by plants and microorganisms. This action enables the identification of adverse effects of fertilization such as leaching, soil erosion, destruction of natural habitats and biodiversity, and it helps to indicate alternative measures to reduce these effects. According to Cissé [68], sustainable fertilization should correct soil nutrient deficiencies, maintain or improve soil fertility, increase yield, improve crop quality, increase farm income and restore the fertility and productivity of soil degraded by abnormal agricultural practices.

Nitrogen management is of key importance for plant production. Therefore, it is particularly important to select appropriate doses of nitrogen fertilizers applied to the soil. Too small doses may result in fierce competition for food between plants and microorganisms, which adversely affects yield. On the other hand, if too high doses of nitrogen fertilizers are used, e.g., urea, apart from the abovementioned economic and environmental aspects (water contamination), this may cause the accumulation of ammonia in soil. In consequence, plants will be poisoned, and the development of beneficial groups of microorganisms will be limited [69-71].

Additionally, it is necessary to remember that nitrogen is also removed from the soil when crops are harvested. However, the lost amounts of nitrogen can be returned to soil with crop residues, which, as an organic fertilizer, will be mineralized by active soil microorganisms. It is assumed that the amount of nitrogen entering soil as a result of the mineralization of legume residues is equal to $25-30 \%$ of the amount of nitrogen accumulated by these plants in the aerial mass. Legumes are an excellent forecrop for cereals, industrial and root crops because if they are used as fertilizers, the yield of succeeding crops increases by up to $15 \%$. When making a nitrogen balance, it is assumed that 1 ton of the dry weight of cereal residues contains about $5-9 \mathrm{~kg} \mathrm{~N}$, whereas 1 ton of the dry weight of maize and rape residues contains 8-12 kg N. Given the average weight of crop residues, the amount of nitrogen that enters soil with them ranges from 15 to $45 \mathrm{~kg} / \mathrm{ha}$ in cereal residues and from 80 to $144 \mathrm{~kg} / \mathrm{ha}$ in winter rape residues. When residues of maize grown 
for silage or grains are applied into soil, the amount of nitrogen that enters the soil with these residues ranges from 40 to $72 \mathrm{~kg} / \mathrm{ha}$ and from 80 to $180 \mathrm{~kg} / \mathrm{ha}$, respectively [72,73].

\section{Microbial Transformations of Organic Nitrogen Forms in Soil}

The conversion of organic forms of nutrients in dead biomass (detritus) into simpler, soluble forms which can be re-absorbed by plants and microorganisms is a key process in any food cycle. Organic nitrogen in soil fractions, crop residues or various types of organic fertilizers is transformed microbiologically into ammonium ions $\left(\mathrm{NH}_{4}{ }^{+}\right)$, which are available to plants (Figure 1) $[4,10]$. These transformations are possible thanks to the mineralization process, which consists of proteolysis and ammonification. The understanding of the concept of mineralization of organic forms of nitrogen is extremely important for sustainable agriculture because it helps to improve the management of crop residues and natural fertilizers, such as solid and liquid manure or slurry. At the same time, it helps to minimize the use of mineral fertilizers and thus avoid the potential problems of groundwater contamination [74]. According to Bailey and Lazarovits [75], crop residues are a renewable resource, and their reapplication to soil allows nutrients to be recycled while increasing crop production and soil fertility. The supply of nitrogen-rich organic matter (narrow C:N ratio-15:1) to soil causes intensive mineralization and increases the availability of this element for plants. As crop residues decompose in the soil, their chemical composition changes considerably, especially their organic nitrogen content. Active microorganisms mineralizing organic matter gain access to carbon and nitrogen contained in it, and they use it to synthesize their own proteins and other organic molecules in the cell.

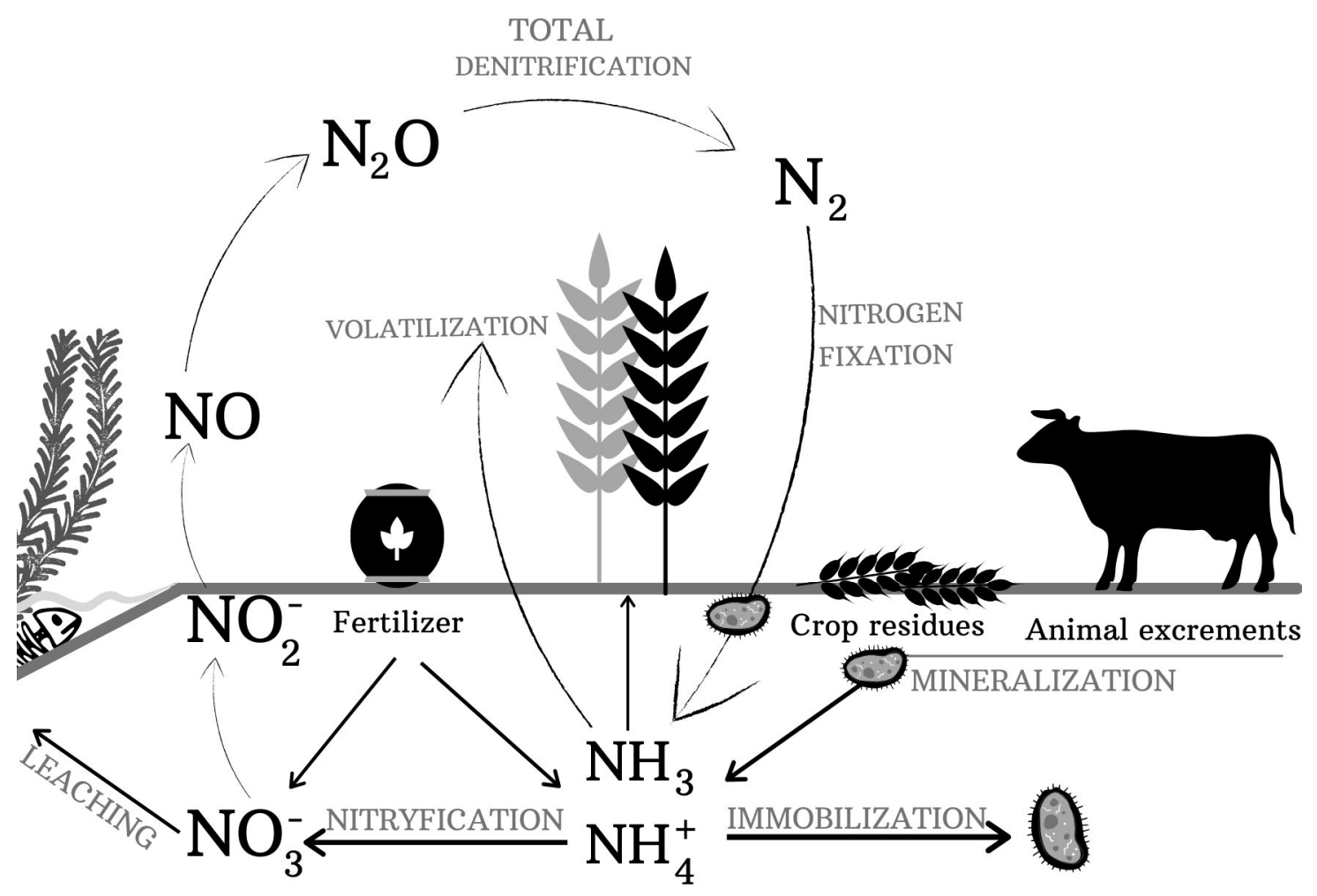

Figure 1. Nitrogen transformations in soil. Source: Authors' original compilation.

Proteolysis is the first stage in the decomposition of nitrogen-based organic matter. It consists of the enzymatic hydrolysis of proteins into peptides and then amino acids. This process is catalyzed by proteolytic enzymes secreted into the environment by heterotrophic microorganisms such as fungi, actinobacteria and bacteria [76,77]. Amino acids formed as a result of proteolysis can be taken up by microorganisms and plants. However, most of them undergo further transformations. According to Rahman et al. [78], 
many soil microorganisms exhibit proteolytic activity, thus ensuring the availability of nutrients. The key proteases produced by microorganisms include alkaline serine endopeptidases (EC 3.4.21) and subtilisin peptidases (EC 3.4.21.62) produced by bacteria, e.g., of the Bacillus and Pseudomonas genera, and by the Aspergillus sp., Penicillium sp., Pythium sp., Trychophyton sp. and Cladosporium herbarum fungi. Apart from that, these are cysteine endopeptidases (EC 3.4.22) produced by bacteria of the Clostridium, Micrococcus, Microsporum and Streptococcus genera, as well as aspartyl endopeptidases (EC 3.4.23) produced by fungi and bacteria of the Aspergillus, Candida, Mucor, Saccharomyces and Shewanella genera [79-84]. Metalloendoproteinases (EC 3.4.24), which require the participation of metals (usually $\mathrm{Zn}^{2+}$ ), also significantly contribute to protein mineralization. They include thermolysin (EC 3.4.24.27) and neutral proteases (EC 3.4.24.28-31) produced by Bacillus sp., Aspergillus oryzae, Proteus aeruginosa and Streptomyces sp. [77]. Apart from that, keratinolytic serine proteases (EC 3.4.4.25) of soil bacteria and fungi play an important role in the recycling of keratin residues [85]. Acid proteinases (EC 3.4.23) are an important group of proteolytic enzymes of fungal origin (Saccharomyces sp., Aspergillus sp., Penicillium sp., Rhizopus sp., Endothia sp.), which are the most active in substrates with pH lower than 5 [86]. Moreover, exopeptidases such as glycine and alanine aminopeptidase (EC 3.4.11) produced by Pseudomonas fluorescens and Lactobacillus lactis are also considered important for the mineralization of organic nitrogen in soil [87-89]. According to Fuka [90] and Fuka [91], $s u b$ and $n p r$ are two typical genes coding for proteolytic enzymes and enabling assessment of the potential proteolytic activity of soil microorganisms. The former gene codes for subtilisins, the latter-for neutral metallopeptidases. According to these authors, the size of the total or proteolytic population of bacteria can only be assumed because microorganisms differ in the number of gene copies per genome. For example, the number of npr copies can range from one (most microorganisms) to seven (Bacillus cereus). Most proteolytic bacteria have one copy of the sub gene, except Bacillus amyloliquefaciens bacteria, which have two copies of this gene. According to Näsholm et al. [92], proteolysis is strongly controlled by $\mathrm{pH}$. It is more intense in acidic soils and positively correlates with organic matter resources in the soil. Both aerobic and anaerobic microorganisms take part in these transformations. Aerobic metabolism predominates on the soil surface and in layers with litter, whereas anaerobic metabolism occurs in deep layers and in wet soils. Research has shown that proteolysis occurs in a wide range of temperatures $\left(10-60^{\circ} \mathrm{C}\right)$ in soil, and the rate of decomposition of protein substances increases along with the temperature. Protein hydrolysis is strongly correlated with soil moisture because proteases exhibit their optimum activity in a soil aqueous solution $[77,93,94]$. Gardini et al. [95] observed that the activity of proteolytic bacteria was inhibited by the presence of $\mathrm{NaCl}$. Bach and Munch [96] and Fuka et al. [91] proved that the protease activity depended on the depth of the soil profile. The authors observed that the count and activity of proteolytic bacteria tended to decrease at deeper soil layers. Marx et al. [97] and Fuka et al. [91] found that the soil structure also influenced the course of proteolysis, as there was a positive correlation between the clay content and the proteolytic activity of microorganisms. The study by Niewiadomska et al. [98] showed that the count of proteolytic bacteria was determined by the fertilization method and the plant's phase of development. The authors observed the most intense multiplication of these bacteria in the soil fertilized with sewage sludge at the maize germination phase.

Ammonification is the next stage of nitrogen mineralization of organic matter. During this process, low-molecular-weight organic nitrogen compounds (amino acids, urea, purine bases, nucleic acids) enter soil with animal and plant residues and the products of proteolysis are further transformed when ammonia is released [99]. Soil deamination is mostly a biochemical process, which occurs thanks to the presence of deaminases (EC 3.5.1.4), such as asparaginase, urease and cytosine deaminase, secreted by soil microorganisms $[100,101]$. Apart from that, amino acid oxidases (EC 1.4.3.2) and dehydrogenases (EC 1.4.1.5) convert amino acids when ammonia is released [102]. Urease is an enzyme that catalyzes the hydrolysis of urea. $\mathrm{NH}_{3}$ and carbamate are formed. The latter spontaneously decomposes to give another molecule of ammonia and carbonic acid. Amino acid oxidases 
catalyze the oxidative deamination of amino acids to produce $\mathrm{NH}_{3}$, ketoacids and hydrogen peroxide $\left(\mathrm{H}_{2} \mathrm{O}_{2}\right)$ [19]. According to Alur [103], the ammonium ion can also be formed in certain related hydrolytic reactions, involving the cleavage of other $\mathrm{C}-\mathrm{N}$ bonds than peptide bonds. These reactions are catalyzed by amidohydrolases (EC 3.5.1) and amidinohydrolases (EC 3.5.3). Two enzymes from the amidohydrolase group, i.e., asparaginase (EC 3.5.1.1) and glutaminase (EC 3.5.1.2), cleave asparagine and glutamine, respectively, and release $\mathrm{NH}_{4}{ }^{+}$and amino acids, such as aspartate and glutamate. These reactions can be observed in Aspergillus sp., Bacillus sp., Pseudomonas fluorescens, Azotobacter agilis and Streptomyces griseus. According to Szostak et al. [104], the decomposition of amino acids to ammonia and carbon dioxide in soil takes 1-6 days. Next, ammonia is converted to the ammonium ion $\left(\mathrm{NH}_{4}^{+}\right)$in the presence of water in the soil solution. $\mathrm{NH}_{4}{ }^{+}$is a form that can be taken up by plants, remain in the soil solution or be sorbed by the soil sorption complex. According to Alur [103], amino acids can be deaminized by hydrolysis, decarboxylation, reduction, direct deamination or oxidation (Scheme 1).

(1) hydrolytic deamination

$$
\begin{aligned}
& \mathrm{R}-\mathrm{CH}-\mathrm{NH}_{2} \mathrm{COOH}+\mathrm{H}_{2} \mathrm{O} \longrightarrow \mathrm{R}-\mathrm{CH}-\mathrm{OH}-\mathrm{COOH}+\mathrm{NH}_{3} \\
& \mathrm{R}-\mathrm{CH}-\mathrm{NH}_{2} \mathrm{COOH}+\mathrm{H}_{2} \mathrm{O} \longrightarrow \mathrm{R}-\mathrm{CH}_{2}-\mathrm{OH}+\mathrm{CO}_{2}+\mathrm{NH}_{3} \\
& \mathrm{R}-\mathrm{CH}-\mathrm{NH}_{2} \mathrm{COOH}+\mathrm{H}_{2} \mathrm{O} \longrightarrow \mathrm{R}-\mathrm{CHO}+\mathrm{HCOOH}+\mathrm{NH}_{3}
\end{aligned}
$$

(2) deamination by decarboxylation to form amine and its hydrolysis

$$
\begin{aligned}
& \mathrm{R}-\mathrm{CH}-\mathrm{NH}_{2} \mathrm{COOH} \longrightarrow \mathrm{R}-\mathrm{CH}_{2}-\mathrm{NH}_{2}+\mathrm{CO}_{2} \\
& \mathrm{R}-\mathrm{CH}_{2}-\mathrm{NH}+\mathrm{H}_{2} \mathrm{O} \longrightarrow \mathrm{R}-\mathrm{CH}-\mathrm{OH}+\mathrm{NH}_{3}
\end{aligned}
$$

(3) deamination by reduction (with or without decarboxylation)

$$
\begin{aligned}
& \mathrm{R}-\mathrm{CH}-\mathrm{NH}_{2} \mathrm{COOH}+\mathrm{H}_{2} \longrightarrow \mathrm{R}-\mathrm{CH}_{2}-\mathrm{COOH}+\mathrm{NH}_{3} \\
& \mathrm{R}-\mathrm{CH}-\mathrm{NH}_{2} \mathrm{COOH}+\mathrm{H}_{2} \longrightarrow \mathrm{R}-\mathrm{CH}_{3}+\mathrm{CO}_{2}+\mathrm{NH}_{3}
\end{aligned}
$$

(4) direct deamination (in anaerobic bacteria)

$$
\mathrm{R}-\mathrm{CH}_{2}-\mathrm{CH}-\mathrm{NH}_{2} \mathrm{COOH} \longrightarrow \mathrm{R}-\mathrm{CH}: \mathrm{CH}-\mathrm{COOH}+\mathrm{NH}_{3}
$$

(5) deamination by oxidation

$$
\mathrm{R}-\mathrm{CH}-\mathrm{NH}_{2} \mathrm{COOH}+\mathrm{O}_{2} \longrightarrow \mathrm{R}-\mathrm{COOH}+\mathrm{CO}_{2}+\mathrm{NH}_{3}
$$

Scheme 1. Types of deamination of amino acids (1-5).

The ammonification process takes place in soil with a wide tolerance of environmental factors due to large diversity among groups of ammonifying microorganisms, which include aerobes and anaerobes, psychrophiles, mesophiles and thermophiles, as well as organisms adapted to acidic and alkaline environments and a wide range of substrate moisture $[105,106]$. Research has shown that the following environmental factors influence the ammonification process: temperature, $\mathrm{pH}, \mathrm{C}: \mathrm{N}$ ratio, the content of nutrients and soil conditions (soil type and structure, its aeration and water retention capacity). The studies conducted by Vymazal [107], Vymazal et al. [108] and Saeed and Sun [109] showed that the optimal $\mathrm{pH}$ and temperature for the ammonification process are 6.5-8.5 and $40-60{ }^{\circ} \mathrm{C}$, respectively. The rate of ammonification doubles as the temperature increases by $10^{\circ} \mathrm{C}$. The ammonification process involves numerous bacteria (Bacillus sp., Clostridium sp., Proteus sp., Pseudomonas sp., Serratia sp. and Escherichia coli), actinobacteria (Streptomyces sp., Micromonospora sp. and Nocardia sp.) and fungi (Aspergillus sp., Mucor sp., Cladosporium sp., Botrytis sp. and Trichoderma sp.) $[76,110]$. 


\section{Microbial Transformations of Mineral Nitrogen in Soil}

\subsection{Immobilization}

Microbial nitrogen immobilization consists of the uptake of nitrogen in the form of ammonium, nitrate or amine into microbial cells in order to further use this element for the synthesis of high-molecular-weight intracellular compounds containing nitrogen (Figure 2) [102,111]. According to Bottomley et al. [112], both bacteria and fungi participate in the immobilization of inorganic nitrogen forms in soil, but the rate of this process is different. According to Li et al. [113], due to the high diversity and complexity of soil microorganisms, it seems difficult to quantify nitrogen immobilization indicators. Moreover, at present, it is not exactly known how much inorganic nitrogen can be immobilized by the community of soil microorganisms. According to Myrold and Posavatz [114], due to the threadlike appearance of cells, fungi usually take up nitrogen in the form of low motility $\mathrm{NH}_{4}{ }^{+}$ions, whereas bacteria exhibit greater potential for using $\mathrm{NO}_{3}{ }^{-}$, especially in the absence of exogenous organic carbon sources. According to Grzyb et al. [115], the immobilization of nitrogen by soil microorganisms significantly affects the content of inorganic nitrogen in soil and thus influences the degree of nutrition and productivity of plants. According to Grzebisz [116] and Grzyb [115], a C:N ratio ranging from 25:1 to 30:1 is often considered to be the critical point between immobilization and mineralization. When crop residues with a high C:N ratio (above 30:1) enter soil, nitrogen in the microbial biomass is immobilized (nitrogen proteinization process), and it becomes less available to plants. According to Chen et al. [117], in 't Zandt et al. [118] and Montaño et al. [119], crop residues directly affect the microbial immobilization of nitrogen. According to Yevdokimov et al. [111], this process also has advantages because immobilization and remineralization cycles ensure the long-term positive effect of nitrogen on soil fertility and plant nutrition. In addition, immobilization delays the loss of nitrogen from fertilizers by leaching or volatilization of gaseous compounds, which helps to control the resistance of soil ecosystems to contamination with fertilizers. Apart from microbial immobilization in soil, there is also abiotic immobilization, during which phenolic compounds derived from the decomposition of crop residues react with ammonia $\left(\mathrm{NH}_{3}\right)$ and nitrite ions $\left(\mathrm{NO}_{2}{ }^{-}\right)$in condensation and nitrosation reactions, respectively, to form organically bound nitrogen [120-122].

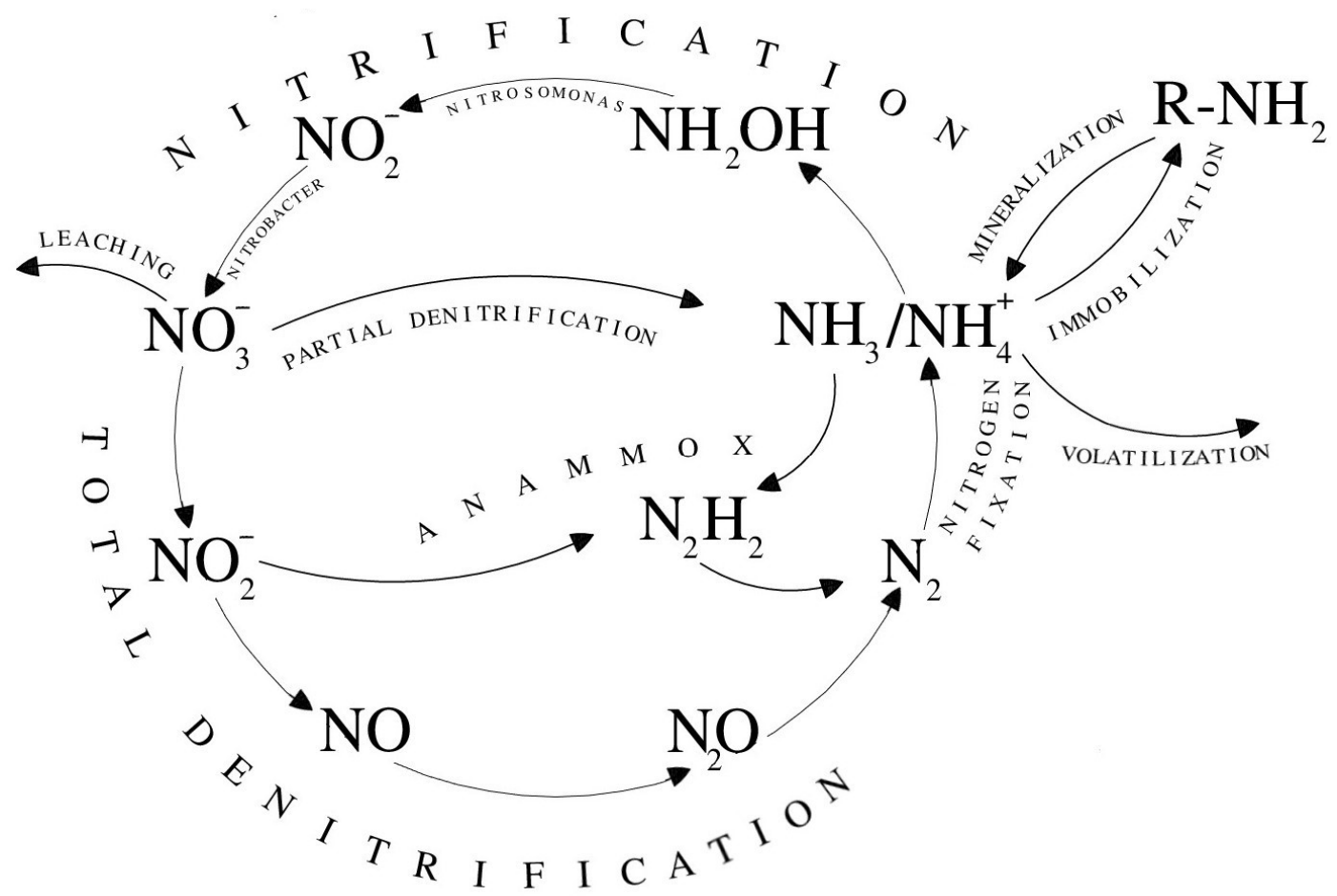

Figure 2. The nitrogen cycle. Source: Authors' original compilation. 


\subsection{Nitrification}

Nitrification is another key process of the transformation of nitrogen compounds in soil. It consists of the transformation of ammonium ions into nitrates under aerobic conditions [1].

The first stage of the nitrification process is known as nitritation. It consists of the oxidation of ammonia $\left(\mathrm{NH}_{3}\right)$ to nitrite $\left(\mathrm{NO}_{2}{ }^{-}\right)$by nitrosobacteria (AOB-ammonia-oxidizing bacteria). These bacteria initiate this transformation through hydroxylamine $\left(\mathrm{NH}_{2} \mathrm{OH}\right)$, which is intermediate. The reaction requires two different enzymes, ammonium monooxygenase (AMO) and hydroxylamine oxidoreductase (HAO), which are encoded by the amo and hao genes, respectively (Scheme 2) [123]. AMO is an enzyme associated with various cytoplasmic membrane subunits, which are responsible for the conversion of ammonia into hydroxylamine. The amo genes are used as functional markers for $\mathrm{AOB}$ in the environment. The amo operon consists of at least three genes: $a m o C$, amo $A$ and $a m o B$, where $a m o A$ encodes a subunit containing the active site of the enzyme. HAO transfers four electrons from the oxidation of hydroxylamine to cytochrome-554 (Cyc554) [124].

\section{$\mathrm{NH}_{3}+\mathrm{O}_{2} \longrightarrow \mathrm{NO}_{2}^{-}+3 \mathrm{H}^{+}+2 \mathrm{e}^{-}$}

\section{$\mathrm{NH}_{3}+2 \mathrm{H}^{+}+\mathrm{O}_{2}+2 \mathrm{e}^{-} \stackrel{\text { ammonia monooxygenase }}{\longrightarrow} \mathrm{NH}_{2} \mathrm{OH}+\mathrm{H}_{2} \mathrm{O}$

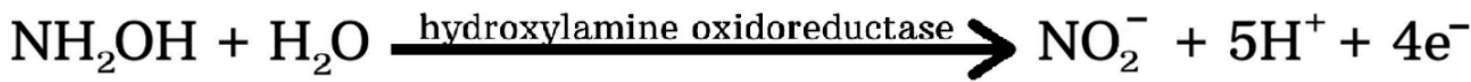

Scheme 2. The transformation of nitrogen compounds in the first stage of nitrification. Author's own source.

Five types of AOB belonging to the Proteobacteria class have been identified and classified on the basis of their phylogenetic relationship. Four of them belong to the $\beta$ Proteobacteria subclass, including Nitrosomonas, Nitrosospira, Nitrosovibrio and Nitrosolobus, whereas Nitrosococcus belongs to the $\gamma$-Proteobacteria subclass. The analysis of the $16 \mathrm{~S}$ rRNA sequence resulted in the division of the Nitrosomonas and Nitrosospira genera into seven clusters (Nitrosospira-clusters 1-4; Nitrosomonas-clusters 5-7), where clusters 2-4 of the Nitrosospira genus were found to be the dominant group in soils $[14,125]$. Archaea (AOA-ammonia-oxidizing archea) are a separate group of microorganisms, which include the Nitrosopumilus maritimu species [14,126,127].

According to Avrahami et al. [128] and Kowalchuk and Stephen [129], the structures of the $\mathrm{AOB}$ community are influenced by soil conditions, such as $\mathrm{pH}$ and humidity, because soil water limits the diffusion of air into soil and the inflow of nitrogen fertilizers. De Boer and Kowalchuk [130] and Nicol et al. [131] analyzed the influence of $\mathrm{pH}$ on the rate of ammonia oxidation in soil and found that it decreased in acidic soils. The authors explained this reaction by the reduced growth and activity of $\mathrm{AOB}$ under the influence of a low $\mathrm{pH}$, the reduced $\mathrm{NH}_{3}$ availability by ionization to $\mathrm{NH}_{4}{ }^{+}$, the reduction of $\mathrm{NH}_{3}$ diffusion and the increased demand for energy-dependent $\mathrm{NH}_{4}{ }^{+}$transport. Moreover, Morimoto et al. [132] proved that AOAs exhibited greater adaptability to low $\mathrm{pH}$ and low oxygen environments than AOBs. The type of fertilizer is another factor that influences nitrosobacteria. Enwall et al. [133] observed the most diverse AOB community in the soil fertilized with manure.

Nitratation, i.e., the oxidation of nitrites $\left(\mathrm{NO}_{2}{ }^{-}\right)$to nitrates $\left(\mathrm{NO}_{3}{ }^{-}\right)$, is the second stage of nitrification (Scheme 3). A separate group of prokaryotes is involved in this process; these nitrobacteria are known as nitrite-oxidizing bacteria (NOB). According to Bernhard [134], the NOB group includes the following genera: Nitrospira, Nitrobacter, Nitrococcus and Nitrospina. The key enzyme of NOB is nitrite oxidoreductase (NXR). There are two phylogenetically distinct forms of this cytoplasmic membrane-bound enzyme: the cytoplasmic type (Nitrobacter sp., Nitrococcus sp. and Nitrolancetus sp.) and the periplasmic type (Nitrospira sp. and Nitrospina sp.) $[135,136]$. The $n x r A$ gene and especially the $n x r B$ 
gene are powerful functional and phylogenetic markers for the detection and identification of uncultured NOB [137].

\section{$\mathrm{NO}_{2}^{-}+\mathrm{H}_{2} \mathrm{O} \longrightarrow \mathrm{NO}_{3}^{-}+2 \mathrm{H}^{+}+2 \mathrm{e}^{-}$}

Scheme 3. The transformation of nitrogen compounds in the second stage of nitrification.

Nitrification bacteria are typical chemoautotrophs because they use part of the energy obtained from both oxidation processes to assimilate carbon dioxide, which is bound in the Calvin-Benson cycle by the carboxylase enzyme (ribulose-1,5-bisphosphate oxygenaseRubisCO) [124,138]. Nitrosobacteria gain $234 \mathrm{~kJ} / \mathrm{mol}$ from the conversion of ammonia into nitrites, whereas nitrobacteria gain $74 \mathrm{~kJ} / \mathrm{mol}$ in the nitratation process [139]. As much as $80 \%$ of the energy produced by these bacteria is absorbed to assimilate $\mathrm{CO}_{2}$ and for cell growth (Wong et al., 2003). There is a constant dependence in the ratio of assimilated carbon to oxidized nitrogen between these reactions. The ratio is 1:35 for the first phase nitrifiers and 1:135 for the second phase nitrifiers [140].

The $\mathrm{NO}_{2}{ }^{-}$ions produced in the first stage of nitrification rarely accumulate in most soils because they are quickly oxidized into $\mathrm{NO}_{3}{ }^{-}$ions [141]. According to Zhu et al. [142], gaseous nitrogen oxide $(\mathrm{NO})$ may also be formed during the nitrification process. This is a by-product of the chemical decomposition of hydroxylamine during the oxidation of $\mathrm{NH}_{3}$. On the other hand, if there is an oxygen deficiency, both $\mathrm{NO}$ and $\mathrm{N}_{2} \mathrm{O}$ can be formed as a result of the $\mathrm{NO}_{2}{ }^{-}$reduction.

The rate of growth of nitrifying bacteria in soil is controlled by oxygen, temperature, $\mathrm{pH}$ and substrate concentration. Strains of nitrifying bacteria develop optimally at $25-30{ }^{\circ} \mathrm{C}$ and at substrate concentrations of $1-25 \mathrm{mM}$. Nitrifying bacteria are sensitive to the end products they make. According to Schultze and Mooney [143], the growth of Nitrosomonas is inhibited by nitrites in the substrate at a concentration of $300 \mathrm{mg} / \mathrm{g}$, whereas the proliferation of bacteria of the Nitrobacter genus is inhibited by nitrates at a concentration of $4000 \mathrm{mg} / \mathrm{g}$. The optimal $\mathrm{pH}$ for the development of nitrifying bacteria is 7-9. They can also be isolated from soils with a $\mathrm{pH}$ of 3 , but their growth in a substrate with a $\mathrm{pH}$ below 6 is significantly limited [130]. Beeckman et al. [144] and Schulze and Mooney [143] observed that sufficient amounts of phosphorus $(\mathrm{P})$, calcium $(\mathrm{Ca})$ and other macronutrients in soil and an appropriate manganese $(\mathrm{Mn})$-to-copper $(\mathrm{Cu})$ ratio are necessary for the normal course of the nitrification process. The highest concentration of nitrifying bacteria can be found in the upper $(10 \mathrm{~cm})$ layers of soil and in rivers and streams at the sediment-water interface. According to Hofman and Van Cleemput [1], the rate of the nitrification process is also influenced by the availability of oxygen and soil water potential. At a water potential of $0 \mathrm{kPa}$, there is little air in the soil. As a consequence, nitrification is inhibited. The fastest rate of the process is at a water potential of at least $-33 \mathrm{kPa}$ for soils with medium and heavy textures and at $-10 \mathrm{kPa}$ for sandy soils. Soil salinity is also one of the main abiotic factors responsible for the rate of nitrogen transformations in the soil environment. Akhtar et al. [145] analyzed the influence of different salinity levels $(9,17,27 \mathrm{dS} / \mathrm{m})$ on nitrogen transformations in the soil fertilized with urea and ammonium sulfate. The researchers observed that the salinity levels of 17 and $27 \mathrm{dS} / \mathrm{m}$ inhibited the second stage of nitrification and caused the accumulation of nitrites $\left(\mathrm{NO}_{2}{ }^{-}\right)$in the soil. Moreover, the highest salinity level of $27 \mathrm{dS} / \mathrm{m}$ inhibited the first stage of nitrification. It caused the accumulation of nitrogen in the form of ammonia, which was lost into the atmosphere due to volatilization. According to Podlaska and Russel [146], the nitrification process can also be inhibited by other substances in the environment, such as methane, ethylene, carbon monoxide, ethane, chloroethane and thiocarbamide. As resulted from scientific publications, some heterotrophic microorganisms are also capable of nitrification, but their efficiency is much lower than that of autotrophic bacteria. Heterotrophic nitrification is the conversion of ammonia to nitrate in the presence of an organic substrate, which is necessary to provide energy to oxidize ammonium ions. Studies have shown that this process is carried out 
by a wide phylogenetic range of soil bacteria and fungi, e.g., Pseudomonas sp., Bacillus sp., Streptomyces sp., Arthrobacter sp., Paracoccus pantotrophus, Aspergillus flavus, Cephalosporium sp. and Penicillium sp. $[14,143]$. These organisms oxidize not only ammonium ions but also hydroxamic acids, oximes, amine oxides, nitroso and nitro compounds. Nevertheless, in most cases, neither the biochemical mechanisms of these processes nor their ecological significance has been well investigated.

\subsection{Denitrification}

In contrast to nitrification, denitrification is an anaerobic process in which denitrifying bacteria catabolize carbon substrates into energy (ATP), using reactive nitrogen forms as the ultimate electron acceptors in respiratory metabolism. The microorganisms carrying out this process are relative anaerobes, which, in aerobic conditions, gain energy by oxidizing various organic and mineral compounds with oxygen from the air. The same microorganisms, under anaerobic conditions, reduce nitrates (or nitrites), taking from them the oxygen they need for energy processes [147]. During this process, nitrate ions are converted into dinitrogen gas $\left(\mathrm{N}_{2}\right)$, which is the end product of this process, or into other gaseous intermediate forms of nitrogen such as ammonia $\left(\mathrm{NH}_{3}\right)$ or nitrous oxide $\left(\mathrm{N}_{2} \mathrm{O}\right)$, which is considered a greenhouse gas (Scheme 4). Complete denitrification takes place when the content of free oxygen in the soil atmosphere decreases. In cultivated mineral soils, where oxygen has easy access and which contain relatively small amounts of organic matter and nitrate, this process does not occur $[8,148]$.

\section{A. $2 \mathrm{NO}_{3}^{-} \longrightarrow \mathrm{O}_{2}+2 \mathrm{NO}_{2}^{-}$

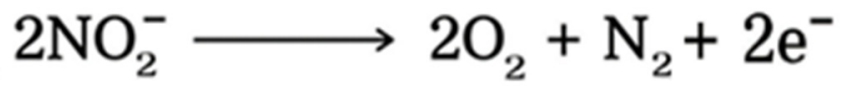 \\ $2 \mathrm{HNO}_{2} \longrightarrow \mathrm{O}_{2}+\mathrm{H}_{2} \mathrm{O}+\mathrm{N}_{2} \mathrm{O}$}

\section{B. $2 \mathrm{NO}_{3}^{-} \longrightarrow \mathrm{O}_{2}+2 \mathrm{NO}_{2}^{-}$ $\mathrm{HNO}_{3}+\mathrm{H}_{2} \mathrm{O} \longrightarrow \mathrm{NH}_{3}+2 \mathrm{O}_{2}$}

Scheme 4. The course of (A) total and (B) partial denitrification.

The process of bacterial denitrification consists of four reactions catalyzed by the enzyme complex: nitrate reductase (nar), nitrite reductase (nir), nitric oxide reductase (nor) and nitrous oxide reductase (nos) (Scheme 5) [14]. The first stage of the process, which consists in the reduction of nitrates to nitrites, is catalyzed by the nar enzyme, which is bound to the cytoplasmic membrane and the periplasm of the bacterial cell. The nar enzyme contains molybdenum (Mo). It is encoded by the narG, narH, narI, narJ, nap $A$ and $n a p B$ genes. Two nir enzymes with different structures are responsible for the reduction of $\mathrm{NO}_{2}{ }^{-}$to $\mathrm{NO}$, which occurs in the second stage of denitrification. One of these enzymes contains copper ( $\mathrm{Cu}-\mathrm{Nir})$ and is encoded by the nirK gene. The other one contains prosthetic groups, hem c and hem $\mathrm{d} 1$ (cd1-Nir), and is encoded by the nirS gene. The third stage of denitrification is catalyzed by the nor enzyme, which is a product of the nor $\mathrm{B}$ and nor $\mathrm{C}$ genes. The conversion of $\mathrm{NO}$ into $\mathrm{N}_{2} \mathrm{O}$ is very important because it results in the formation of a bond between nitrogen molecules. The nos enzyme is involved in the last stage of the denitrification process. This enzyme contains copper $(\mathrm{Cu})$ and is encoded by the nos $R$ and nosZ genes [149]. 


\section{$2 \mathrm{NO}_{3}^{-} \stackrel{\text { nar }}{\longrightarrow} 2 \mathrm{NO}_{2}^{-} \stackrel{\text { nir }}{\longrightarrow} 2 \mathrm{NO} \stackrel{\text { nor }}{\longrightarrow} \mathrm{N}_{2}^{\uparrow} \stackrel{\text { nos }}{\longrightarrow} \stackrel{\uparrow}{\longrightarrow} \mathrm{N}_{2}$}

Scheme 5. The enzymes involved in denitrification.

Denitrification mostly occurs in flooded soils and low-oxygen zones in lakes and oceans. The functional group of denitrifying microorganisms includes a large number of bacteria from different taxonomic units, which differ significantly in the specifics of their substrate (electron donor). According to Schulze and Mooney (2002), most denitrifying bacteria are heterotrophs of the following genera: Alcaligenes, Bacillus, Paracoccus, Thiobacillus, Burkholderia, Thaurea, Rubrivax and Ralstonia. The following species are also capable of denitrification: Achromobacter sp., Agribacterium sp., Alcaligenes sp., Flavibacterium sp., Serratia sp., Spirillum sp. and Micrococcus sp. Pseudomonas bacteria isolated from both soil and water sediments, such as $P$. stutzeri and P. perfectomarinus species, are also classified as denitrifiers. They have often been used as models in studies on the specific nature of the denitrification process.

Studies have proved that some bacteria can reduce nitrites or nitrates to gaseous nitrogen compounds in the presence of oxygen. Su et al. [150] observed that the denitrifying bacteria Paracoccus denitrificans reduced $27 \%$ of the nitrate added to the medium into gaseous nitrogen in an atmosphere containing $92 \% \mathrm{O}_{2}$. Japanese scientists Matsuzaka et al. [151] and Okada et al. [152] isolated aerobic denitrifying bacteria of the Mesorhizobium genus and Burkholderia cepacian species from soil.

From the results of scientific publications, selected species of moulds (Aspergillus nidulans, Fusarium oxysporum, Fusarium decemcellulare, Trichoderma hamatum, Talaromyces flavus and Chaciomhun sp.) are capable of denitrification [76,153-155]. Studies by Laughlin and Stevens [156] and McLain and Martens [157] showed that fungal denitrification mostly occurs in forest soils, meadows and semi-arid regions. Shoun [158] studied the biochemical mechanisms and physiological role of fungal denitrification in soil. He tested pure cultures of ascomycetes (Cylindrocarpon tonkinense and Gibberella fujikuroii) and basidiomycetes (Trichosporon cutaneum) and observed that the denitrification process occurs in fungal mitochondria and is coupled with ATP synthesis. Cabello et al. [159] found that hyperthermophilic (Pyrobaculum aerophilum and Ferroglobus placidus) and halophilic species (Haloferax sp. and Haloarcula sp.) of archaea were also capable of denitrification. The authors proved that, similar to bacteria, archaea are involved in the dissimilatory reduction of nitrates through $\mathrm{NO}_{2}{ }^{-}, \mathrm{NO}$ and $\mathrm{N}_{2} \mathrm{O}$ into $\mathrm{N}_{2}$. However, biochemical analyses and genome sequence analyses revealed that archaea differed from bacteria in the organization of the genes encoding denitrifying enzymes and in the structure and regulation of these enzymes. Only a few operons are preserved in all or most of the genomes of bacteria and archaea. For example, in some archaea, the organization of the narGHJI operon is not preserved, nor do they have the narI genes located near the narGHJ [160].

The course of the denitrification process is influenced by various factors, e.g., the oxygen content, the availability of electrons in organic carbon compounds, soil pH, ambient temperature and inhibitors of denitrifying enzymes. Denitrification is inhibited by acetylene, azide, cyanide, 2,4-dinitrophenol, nitrapyrin, pesticides, sulfates and sulfides. $\mathrm{N}_{2} \mathrm{O}$ reductase is an enzyme that is particularly sensitive to the $\mathrm{pH}$ of the medium, the presence of acetylene, CO, azide and cyanide [143]. Stremińska and Błaszczyk [161] studied the influence of the $\mathrm{pH}$ value on the course of the denitrification process and found that it was the most intensive in substrates with a $\mathrm{pH}$ of 6-8. It was also observed in acidic soils, e.g., in forest soils with a high content of nitrates. The rate of denitrification is closely related to the availability of organic substrate. Therefore, the process may be optimized by adding manure or crop residues to soil. The denitrification process is also influenced by the soil texture, which significantly affects soil aeration and water content and thus the activity of denitrifying microorganisms [148,162]. According to Payne et al. [163], the denitrification 
process is also stimulated by plant root secretions, which are rich in easily degradable carbon compounds, amino acids and vitamins. These findings were confirmed by Zhang et al. [164], who clearly concluded that the presence or absence of plants influenced the amount of $\mathrm{N}_{2} \mathrm{O}$ in soil.

Denitrification is a negative process from the agricultural point of view. Total denitrification results in gaseous forms of nitrogen escaping from soil. According to [76,134], this process is particularly important for the transformation of nitrogen compounds in the environment because nitrates are removed from the soil ecosystem and returned to the atmosphere in a biologically inert form $\left(\mathrm{N}_{2}\right)$.

\subsection{Codenitrification}

Codenitrification, also known as biotic nitrosation, is another process that takes place in the soil environment. The process consists of the formation of $\mathrm{N}_{2} \mathrm{O}$ and $\mathrm{N}_{2}$, where one $\mathrm{N}$ atom comes from an inorganic $\mathrm{N}$ compound (e.g., $\mathrm{NO}_{2}{ }^{-}$), whereas the other one comes from a co-metabolized organic compound, such as amines, azide, salicylhydroxamic acid or hydroxylamine. This process is the most intensive in nearly neutral to alkaline soils, both in grasslands and in agricultural soils [165,166]. Long et al. [167] and Spott et al. [166] found that both fungi (Fusarium oxysporum, Fusarium solani and Cylindrocarpon tonkinense) and bacteria (e.g., Streptomyces antibioticus, Corynebacterium nephridia, Pseudomonas denitrificans, Paracoccus denitastrificans, Rhodoclastobacter sphacterides and Mesorhizobium sp.) were involved in biotic nitrosation.

\subsection{Anammox}

In 1999, Strous et al. [168] discovered a new type of ammonia oxidation occurring under anaerobic conditions and called it anammox (anaerobic ammonia oxidation). Anammox bacteria are the second largest group of microorganisms after denitrifiers that live in an anaerobic environment. They oxidize ammonia (electron donor) using nitrite as an electron acceptor and $\mathrm{CO}_{2}$ as a source of carbon and form gaseous $\mathrm{N}_{2}$ under anaerobic conditions [169]. Hydroxylamine $\left(\mathrm{NH}_{2} \mathrm{OH}\right)$ and hydrazine $\left(\mathrm{N}_{2} \mathrm{H}_{4}\right)$ are intermediates in this process (Scheme 6). Studies by Ali et al. [170], Oshiki et al. [171] and Strous et al. [172] showed that the genome of anammox bacteria includes several genes (narK, foc $A$ and $a m t B$ ) responsible for substrate transport. Having been transported into the cell, the substrates are converted into intermediates $\left(\mathrm{NH}_{2} \mathrm{OH}, \mathrm{N}_{2} \mathrm{H}_{4}\right)$ in a reaction catalyzed by the nitrite reductase nirS enzyme or its nirK homologue. Moreover, the reactions in which hydrazine is formed and oxidized are catalyzed by hydrazine synthetase, encoded by the hzs gene, and hydrazine oxidoreductase, encoded by the hzo gene. In comparison with denitrification, anammox is an ecologically advantageous and less toxic process because gaseous nitrogen is produced $\left(\mathrm{N}_{2}\right)$ without intermediate gases $\left(\mathrm{NO}_{\mathrm{x}}\right)$. All these reactions take place in the anammoxosome (Figure 3), which is an intracytoplasmic compartment bounded by a single membrane containing tightly packed ladder lipids (ladderanes). Ladderanes make the cell membrane denser and stiffer, thus minimizing the loss of gaseous intermediates such as nitric oxide (NO) and hydrazine $\left(\mathrm{N}_{2} \mathrm{H}_{4}\right)$. The anammoxosome fills 50-70\% of the cell and functions similarly to the mitochondria in eukaryotes [173,174]. Research by Han and Gu [175] and Schmid et al. [176] showed that seven genera of prokaryotes belonging to the Planctomycetes phylum (Brocadia, Anammoxoglobus, Kuenenia, Scalindua, Jettenia, Brasillis and Anammoximicrobium) were involved in the anammox process. Initially, it was assumed that Planctomycetes lacked peptidoglycan, the universal polymer of the bacterial cell wall. However, the research by van Teeseling et al. [177] showed that the Kuenenia stuttgartiensis anammox bacteria of the Planctomycetes phylum had a thin murein layer under the outer cell membrane, which corresponded to the typical peptidoglycan characteristics of Gram-negative bacteria. Moreover, unlike in Gram-negative bacteria, the Kuenenia stuttgartiensis cell wall is not surrounded by one outer membrane and one inner membrane. Instead, it has two inner membranes, mostly composed of proteins [178]. 


\section{$\mathrm{NH}_{4}^{+}+\mathrm{NO}_{2}^{-} \longrightarrow \mathrm{N}_{2} \mathrm{H}_{2} \longrightarrow \mathrm{N}_{2}$}

Scheme 6 . The course of the annamox reaction.

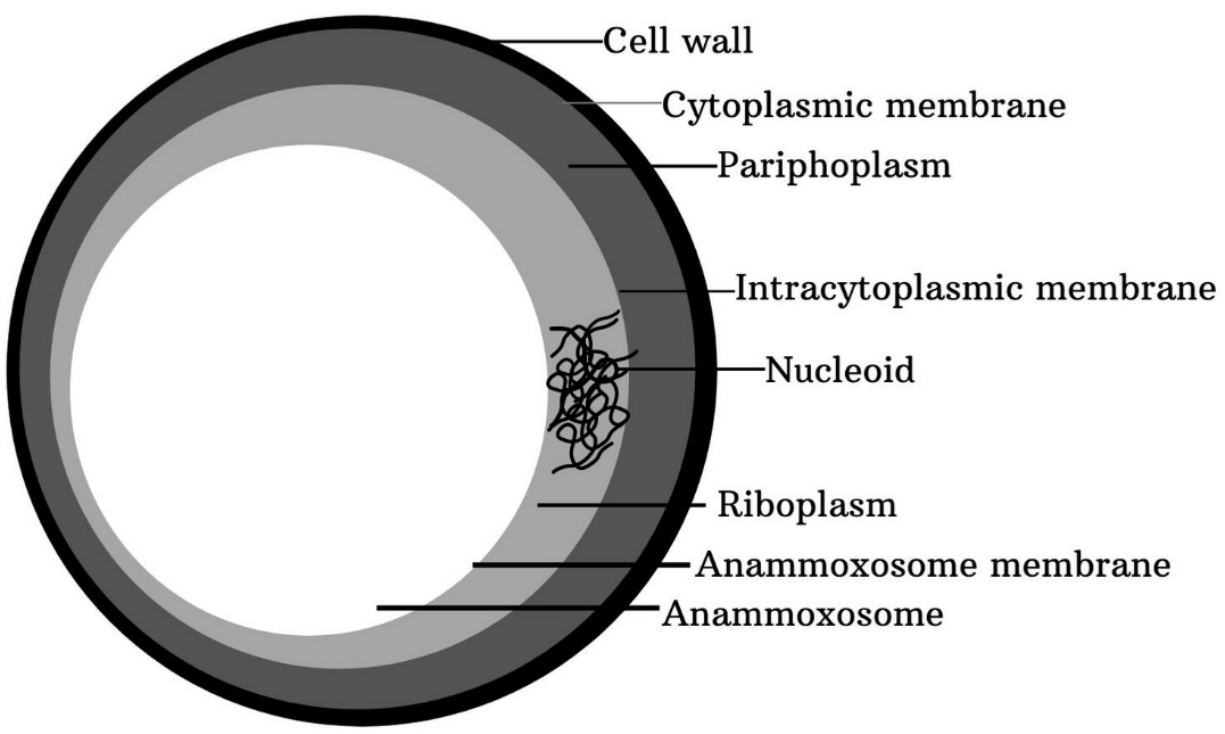

Figure 3. The Planctomycetes cell structure. Source: Authors' original compilation.

The anammox process is influenced by the slow growth of anammox bacteria and their high sensitivity to changes in environmental conditions, such as temperature, $\mathrm{pH}$ of the environment and substrate concentration. The optimal $\mathrm{pH}$ and temperature for the growth and activity of anammox microorganisms are 6.7-8.3 and $20-43^{\circ} \mathrm{C}$, respectively. However, depending on the species, these bacteria can also grow within a wide range of temperatures, i.e., from $-2{ }^{\circ} \mathrm{C}$ to $85^{\circ} \mathrm{C}$ [179-183]. According to Gao and Tao [184], Pereira et al. [185] and Tomaszewski et al. [186], the course of the anammox process is also significantly influenced by the content of substrates, i.e., nitrites and ammonia. Free ammonia $\left(\mathrm{NH}_{3}\right)$ and free nitrous acid $\left(\mathrm{HNO}_{2}\right)$ can strongly inhibit the anammox process. Jaroszynski et al. [187] and Jung et al. [188] described the lowest inhibitory concentrations of ammonia, i.e., 1.7 and $2.0 \mathrm{mg} \mathrm{N} / \mathrm{L}$. Moreover, Jaroszynski [189] found that anammox bacteria were very sensitive to salination. $\mathrm{NaCl}$ concentrations above $150 \mathrm{mM}, \mathrm{KCl}$ concentrations above $100 \mathrm{mM}$ and $\mathrm{Na}_{2} \mathrm{SO}_{4}$ concentrations above $50 \mathrm{mM}$ had a negative influence on the course of this process. The activity of anammox bacteria was completely inhibited at $1 \mathrm{mmol} / \mathrm{L}$ $\mathrm{HgCl}_{2}$. The study by Dapena-Mora et al. [190] showed that phosphates and sulfides are two inorganic inhibitors of the anammox process. Under anaerobic conditions, the $\mathrm{SO}_{4}{ }^{2-}$ ion is reduced to $\mathrm{H}_{2} \mathrm{~S}$, which inhibits bacterial activity. Hu et al. [191] described the presence of slow-release organic matter (e.g., humic acids) as an important factor influencing the distribution of anammox bacteria of the Brocadia and Jettenia genera in peat soil. Other scientific publications also show that annamox bacteria are widespread in marine ecosystems, freshwater and subtropical lakes, as well as in wetlands [192-194]. Humbert et al. [195] provided a lot of evidence for the presence of anammox bacteria in various soil environments. These microorganisms were found in soil samples from wetlands, lakeshores, farmlands and those with nitrophilic or nitrogen-fixing plants.

\subsection{Nitrogen-Fixing}

Although molecular nitrogen makes up almost $80 \%$ of the Earth's atmosphere, plants and animals cannot assimilate it due to its very low reactivity. The gaseous form $\mathrm{N}_{2}$ is very stable because it has a triple bond between nitrogen atoms and requires a large amount of energy to be broken (Scheme 7). As a result, only selected groups of prokaryotes, known 
as diazotrophs, including heterotrophic bacteria, archaea and cyanobacteria, are able to carry out the energetically demanding process of binding molecular nitrogen $\left(\mathrm{N}_{2}\right)$ and incorporating it into organic compounds [196]. Some nitrogen-fixing organisms are freeliving bacteria (Azotobacter sp., Azomonas sp., Azospirillum sp., Bacillus sp., Beijerinckia sp., Calothrix sp., Clostridium sp., Derxia sp., Desulfovibrio sp., Nostoc sp., Rhodobacter sp., Rhodospirillum sp.), whereas others make symbiotic systems with plants (rhizobia-Rhizobium sp., Allorhizobium sp., Azorhizobium sp., Bradyrhizobium sp., Mesorhizobium sp., Sinorhizobium sp.) [143,153]. According to Herridge et al. [197] and Łyszcz and Gałązka [198], every year, about 139-170 million tons of nitrogen is provided to arable soils around the world through the process of biological fixation of atmospheric nitrogen. The amount of nitrogen fixed by microorganisms living in symbiotic systems ranges from about $70 \%$ to $80 \%$; the remaining $20-30 \%$ is fixed by non-symbiotic microorganisms $[199,200]$. The research by Natywa et al. [201] and Schulze and Mooney [143] showed that 100-200 kg N/ha/year is provided by Rhizobium sp. bacteria, which live in symbiosis with legumes. The amount of nitrogen fixed by free-living bacteria is about ten times smaller, i.e., usually $<10 \mathrm{~kg}$ $\mathrm{N} /$ ha/year. According to these authors, only small amounts of atmospheric nitrogen are fixed by free-living diazotrophs because the process occurs only during the growth of these microorganisms. Moreover, nitrogen is not released to the environment immediately but only after the death of bacterial cells.

\section{$8 \mathrm{H}^{+}+\mathrm{N}_{2}+8 \mathrm{e}^{-}+16 \mathrm{MgATP} \longrightarrow 2 \mathrm{NH}_{3}+\mathrm{H}_{2}+16 \mathrm{MgADP}+16 \mathrm{Pi}$}

Scheme 7. The course of the nitrogen fixation reaction.

The diversity of nitrogen-fixing bacteria in aquatic and terrestrial environments is assessed by means of a molecular marker, i.e., the nifH gene. It is a highly conserved gene among various microorganisms. It encodes the nitrogenase component, which catalyzes the reduction of $\mathrm{N}_{2}$ into $\mathrm{NH}_{3}$. The nitrogenase complex encoded by the nifHDK genes consists of an iron metalloprotein (Fe) homodimer, which binds two ATP molecules, and a metalloprotein tetramer containing a molybdenum-iron (Mo-Fe) complex [202,203]. The studies by Siemann et al. [204] and Wielbo and Skorupska [205] showed that the evolution of nifDK genes led to the formation of new variants of the Mo-Fe metalloprotein complex in the tetramer. Molybdenum was replaced by vanadium (V-Fe metalloprotein), e.g., in Azotobacter saliestris, Azotobacter chroococcum and Anabaena variabilis, or the ability to bind atoms of two different metals was lost in favor of iron (Fe metalloprotein), e.g., in Clostridium pasteurianum, Rhodobacter capsulatus, Rhodospirillum rubrum and Azomonas macrocytogenes. The following genes encode both nitrogenases: vnfH, vnfD, vnfG and vnfK, as well as anfH, anfD, anfG and anfK [206]. According to Nordult and Ureta [207], the activity of nitrogenase is mainly limited by the oxygen content or the concentration of hydrogen ions in the environment. The studies by Egamberdieva and Kucharova [208] showed that the season of the year also significantly influenced the count and activity of nitrogen-fixing bacteria. The authors observed higher counts of these microorganisms in the soil in spring. They explained that this phenomenon was caused by the optimal temperature and increased soil moisture due to higher rainfall. According to Vitousek et al. [209], nitrogen fixation is also influenced by the access of rhizobia to micro- and macroelements because molybdenum is necessary for the activity of most nitrogenases. Apart from that, nitrogenfixing microorganisms also need more phosphorus and iron to meet their high demand for ATP and for the normal activity of nitrogenase, which is necessary to fix nitrogen. Additionally, the synthesis and activity of nitrogenase in most nitrogen-fixing organisms are inhibited by high levels of fixed nitrogen. The availability of calcium $(\mathrm{Ca})$ is another factor influencing the efficiency of nitrogen fixation. A decrease in the calcium content in soil reduces the ability of rhizobia to colonize root hairs [210]. The highest nitrogen fixation efficiency of most microorganisms can be observed at $20-25^{\circ} \mathrm{C}$, although the process takes place within a temperature range of $12-35^{\circ} \mathrm{C}$ [211]. Long [212] found that each symbiotic 
system of Rhizobium and legumes had its optimal temperature dependence. It was $25-30{ }^{\circ} \mathrm{C}$ for common beans (Phaseolus vulgaris L.) and about $30^{\circ} \mathrm{C}$ for clover (Trifolium pratense L.) and peas (Pisum sativum L.). The activity of rhizobia is also significantly influenced by the dose of nitrogen fertilizer applied to the soil. Salvagiotti et al. [213] observed a negative exponential relationship between the dose of mineral nitrogen fertilizer and the efficiency of legumes in binding $\mathrm{N}_{2}$. Sellstedt and Richau [214] and van Nguyen and Pawlowski [215] observed the best-known symbiosis resulting in nitrogen fixation between legumes (Fabaceae) and rhizobia. Some rhizobia can induce the formation of nodules in one or more species of legumes, whereas others have a wide range of plant hosts $[198,216]$. The root secretions of legumes (e.g., pea, clover, soybean) are specific attractants, which act as signal substances for some Rhizobium species. Legumes secrete phenolic molecules, mainly flavonoids and isoflavonoids, into the rhizosphere. These signals are captured by rhizobia. A flavonoid-NodD protein interaction occurs on the inner membrane of bacterial cells, and a set of genes responsible for the formation of nodules on the surface of plant roots is activated. In bacteria of the Rhizobium genus, the genes responsible for symbiosis are found on a circular DNA molecule- the symbiotic plasmid (pSym). There are two basic groups of these genes: nod and nol genes-nodulation genes inducing the initiation and development of nodules, and fix and nif genes-fixation and nitrogen fixation genes responsible for atmospheric nitrogen fixation. The group of nodulation genes includes comnod genes (common nodulation genes), which have been found in all rhizobia studied so far, and hsnnod genes (host-specific nodulation genes), which are specific to bacterial species or strains. When nodulation genes are activated, the so-called Nod factor in the signaling molecule is synthesized. Legumes can recognize the Nod factor through NFR receptors, which are composed of two histidine kinases with the extracellular LysM domain. The binding of receptors with Nod factors causes depolarization of the plasma membrane of root hairs through the influx of $\mathrm{Ca}^{2+}$. This process initiates the infectious thread, the penetration of bacteria into the hairs and the formation of growths (nodules), in which the rhizobia turn into a bacteroid form and begin nitrogen fixation in a unique plant organelle known as symbiosome. The symbiosome is bounded by a membrane of plant origin, which controls the exchange of nutrients between symbionts [217-220]. According to Mus [217], the existence of rhizobia in newly formed growths of legumes depends on the sources of carbon and energy from the plant, as well as on phosphorus $(\mathrm{P})$, iron $(\mathrm{Fe})$, sulfur (S), molybdenum (Mo), vanadium (V) and cobalt (Co). There are numerous positive aspects of this symbiosis, such as higher yield as well as the maintenance and restoration of soil fertility. According to scientific publications, thanks to the activity of rhizobia, the yield of legumes can be increased by $10-20 \%$, and there is a higher content of proteins in crops. Research has shown that free-living nitrogen-fixing bacteria enrich soil and plants with nitrogen and increase the yield of crops by $5-15 \%$. In addition, rhizobia also play a significant role in the secretion of growth hormones such as cytokinins, gibberellins and auxins. One of them is indole acetic acid (IAA), which stimulates plant rooting and plays an important role in the formation and development of nodules on the roots of legumes [221]. According to Verma et al. [222], rhizobia also have other advantages; they release phosphates and use molecules of 1-aminocyclopropane-1-carboxylate (ACC), which is a plant ethylene precursor, to protect plants from ethylene stress. Chandra et al. [223] and Verma et al. [222] found some strains of rhizobia to be acting as biocontrol agents. Tamiru and Muleta [224] described the ability of rhizobia isolates to counteract the black rot of broad bean (Vicia faba L.) roots caused by Fusarium solani. Shaukat and Siddiqui [225] observed that pathogens infecting ocher (Abelmoschus esculentus L.) and sunflower (Helianthus L.), such as Macrophomina phaseolina, Rhizoctonia solani and Fusarium solani, were effectively controlled with Bradyrhizobium japonicum, Sinorhizobium meliloti and Rhizobium leguminosarum. Mechanisms of biological control of phytopathogens by rhizobia include competition for nutrients, the production of cell wall-degrading enzymes, antibiotics, siderophores and metabolites such as $\mathrm{HCN}$, phenazines, pyrrolnitrin, viscoinamide and tensin. Król and Zielewicz-Dukowska [226], Martyniuk [227] and Svistoonoff [228] observed symbiotic 
nitrogen fixation in actinobacteria of the Frankia genus, living in symbiosis with woody plants, e.g., with alder (Alnus). The transformation of nitrogen compounds also involves three processes causing the loss of nitrogen from farmlands- the volatilization, leaching and removal of nitrogen from the field with harvested crops.

\subsection{Ammonia Volatilization}

The $\mathrm{pH}$ value is the main factor that may cause the soil nitrogen content to decrease. In an alkaline environment, ammonium ions $\left(\mathrm{NH}_{4}{ }^{+}\right)$dissociate into ammonia, which is then released into the atmosphere (Scheme 8). It is so because ionized ammonia $\left(\mathrm{NH}_{4}{ }^{+}\right)$ is soluble in water, whereas the non-ionized form $\left(\mathrm{NH}_{3}\right)$ is volatile [229]. Meisinger and Jokela [230] and Jones et al. [231] observed that apart from the soil $\mathrm{pH}$, it was also the temperature, type and chemical composition of the organic fertilizer (e.g., manure) that caused the volatilization of ammonia. They found that $\mathrm{NH}_{3}$ volatilized from the soil when $\mathrm{pH}$ was above 7.5 , and the volatilization rate tended to increase along with the temperature. Higher temperature increases the loss of ammonia because its solubility in the soil solution decreases. The composition of manure fertilizers also influences the emission of ammonia from the soil. Differences in the chemical composition of fertilizers (slurry, liquid manure, manure) applied to the soil translate into different values of the soil $\mathrm{pH}$, the amount of $\mathrm{NH}_{4}{ }^{+}$ions formed and the rate of urea hydrolysis. Sommer and Hutchings [232] analyzed a number of empirical models designed to predict the volatilization of $\mathrm{NH}_{3}$ after the application of slurry. The researchers found a linear relationship between the rate of ammonia volatilization from soil and the temperature within the range of $15-25^{\circ} \mathrm{C}$. According to Yang et al. [233] and Zhou et al. [234], every year, about $9.3 \times 10^{6} \mathrm{~mol}$ of $\mathrm{NH}_{3}$ is released into the atmosphere. It reacts with sulfuric, nitric and hydrochloric acids and forms ammonium salts, thus increasing air pollution.

\section{$\mathrm{NH}_{4}^{+}+\mathrm{OH}^{-} \longrightarrow \mathrm{NH}_{3} \uparrow+\mathrm{H}_{2} \mathrm{O}$}

Scheme 8. The ammonia volatilization reaction.

\subsection{Leaching}

Nitrogen is also lost from the soil as a result of leaching (Figure 1). These are nitrites and nitrates that are leached from the rhizosphere [235]. They are very mobile because they are adsorbed on soil particles and are easily moved beyond the soil profile [236]. According to Bolan and Hedley [237], this process is particularly important in areas with heavy rainfall and soils with a light, sandy texture, where as much as $25-50 \%$ of nitrogen may be lost through leaching. According to Davis et al. [238], the amount of nitrogen applied to soil, its water content and permeability are important factors regulating the amount of nitrogen lost through leaching. Leaching reduces the bioavailability of nitrogen to plants and negatively affects the quality of the environment because it causes high concentrations of nitrates in groundwater and indirect emissions of greenhouse gases, e.g., nitrous oxide $\left(\mathrm{N}_{2} \mathrm{O}\right)$. Leaching also increases costs because it is necessary to re-apply mineral fertilizers with nitrogen [239-241].

Additionally, it is necessary to remember that some nitrogen is lost from soil when crops are harvested [242]. For example, the amounts of nitrogen lost from the soil at harvest time may be as high as: $0.3 \mathrm{~kg} \mathrm{~N} / \mathrm{yu}$ (per yield unit) for maize, $0.54 \mathrm{~kg} \mathrm{~N} / \mathrm{yu}$ for wheat, $0.72 \mathrm{~kg} \mathrm{~N} / \mathrm{yu}$ for rape and $1.5 \mathrm{~kg} \mathrm{~N} / \mathrm{yu}$ for soybeans [243].

\section{Conclusions}

The nitrogen cycle in soil is a combination of transformations such as nitrification, denitrification, anammox, mineralization, nitrogen immobilization and leaching. Their discovery gave a new dimension to our understanding of nitrogen transformations. For a long time, the understanding of the role of microorganisms in the transformation of nitrogen compounds was limited by the fact that the vast majority of microorganisms present in the 
ecosystem cannot be cultured using traditional microbiological techniques. Modern tools in genomics and metagenomics have changed our knowledge of microbial communities in the soil environment and their influence on the metabolism of nitrogen compounds. Many human activities significantly influence the nitrogen cycle in the environment. The combustion of fossil fuels and the use of nitrogen fertilizers may increase the amount of bioavailable nitrogen in the soil ecosystem. However, the mismanagement of mineral fertilization may disturb the biological equilibrium in soil and cause the leaching of nitrates, which will pollute streams and rivers, and ultimately contaminate drinking water. Apart from that, as the availability of nitrogen in soil increases, the microbial decomposition of carbon sources intensifies, and thus the amount of humus compounds is reduced. As the long-term influence of agriculture on the environment is a matter of concern in industrialized and developing countries, it is necessary to better understand the nitrogen cycle. Therefore, the Food and Agriculture Organization of the United Nations (FAO) stressed the need to increase food production without degrading the environment and proposed sustainable agricultural practices to achieve this goal [244]. Proper nitrogen management is a challenge not only for Poland but also for Europe because it requires knowledge and social awareness. The proper management of organic and mineral fertilizers, the regulation of soil $\mathrm{pH}$ and the use of microbiological preparations promoting the growth and development of crops are the elements that need to be understood and implemented in order to develop modern, sustainable agriculture and protect the natural environment and the health of present and future generations.

Author Contributions: A.G. prepared and wrote original draft of the manuscript. A.W.-M. and A.N. contributed in reviewing and editing. All authors have read and agreed to the published version of the manuscript.

Funding: This research received no external funding.

Institutional Review Board Statement: Not applicable.

Informed Consent Statement: Not applicable.

Conflicts of Interest: The authors declare no conflict of interest.

\section{References}

1. Hofman, G.; Van Cleemput, O. Soil and Plant Nitrogen; International Fertilizer Industry Association: Paris, France, 2004.

2. Czekała, J. Effect of long-term cultivation of plants without the participation of cereals on the content of nitrogen forms in the humus level of the soil. J. Res. Appl. Agric. Eng. 2010, 55, 49-53.

3. Ohyama, T. Nitrogen as a Major Essential Element of Plants. Nitr. Assim. Plants 2010, 37, 2-17.

4. Robertson, G.P.; Groffman, P.M. Nitrogen transformations. In Soil Microbiology, Ecology and Biochemistry; Paul, E., Ed.; Elsevier: Amsterdam, The Netherlands, 2015; pp. 421-446.

5. Kopcewicz, J.; Lewak, S.; Jaworski, K. Plant Physiology; Scientific Publisher PWN: Warsaw, Poland, 2019.

6. Zboińska, M. How do plants take up and fix nitrogen? Eduk. Biol. Środowisk. 2018, 2, 19-31.

7. Pajares, S.; Bohannan, B.J. Ecology of nitrogen fixing, nitrifying, and denitrifying microorganisms in tropical forest soils. Front. Microbiol. 2016, 7, 1045. [CrossRef] [PubMed]

8. Staszewski, Z. Nitrogen in soil and its impact on the environment. Science notebooks. Civ. Water Eng. Environ. Manag. 2011, 50-58.

9. Cabello, P.; Luque-Almagro, V.M.; Roldán, M.D.; Moreno-Vivián, C. Nitrogen cycle. In Encyclopedia of Microbiology; Schmidt, T., Ed.; Academic Press: Cambridge, MA, USA, 2004; pp. 301-310.

10. Lamb, J.A.; Fernandez, F.G.; Kaiser, D.E. Understanding Nitrogen in Soils; University of Minnesota: Minneapolis, MN, USA, 2014; pp. 1-5.

11. Frenk, S.; Hadar, Y.; Minz, D. Resilience of soil bacterial community to irrigation with water of different qualities under mediterranean climate. Environ. Microbiol. 2014, 16, 559-569. [CrossRef]

12. García-Orenes, F.; Morugán-Coronado, A.; Zornoza, R.; Scow, K. Changes in soil microbial community structure influenced by agricultural management practices in a mediterranean agro-ecosystem. PLoS ONE 2013, 8, e80522.

13. Morugán-Coronado, A.; García-Orenes, F.; McMillan, M.; Pereg, L. The effect of moisture on soil microbial properties and nitrogen cyclers in mediterranean sweet orange orchards under organic and inorganic fertilization. Sci. Total Environ. 2019, 655, 158-167. [CrossRef] [PubMed] 
14. Hayatsu, M.; Tago, K.; Saito, M. Various players in the nitrogen cycle: Diversity and functions of the microorganisms involved in nitrification and denitrification. Soil Sci. Plant Nutr. 2008, 54, 33-45. [CrossRef]

15. Gaby, J.C.; Buckley, D.H. A global census of nitrogenase diversity. Environ. Microbiol. 2011, 13, 1790-1799. [CrossRef] [PubMed]

16. Henry, S.; Bru, D.; Stres, B.; Hallet, S.; Philippot, L. Quantitative detection of the nosZ gene, encoding nitrous oxide reductase, and comparison of the abundances of $16 \mathrm{~S}$ rRNA, narG, nirK, and nosZ genes in soils. Appl. Environ. Microbiol. 2006, 72, 5181-5189. [CrossRef]

17. Pester, M.; Maixner, F.; Berry, D.; Rattei, T.; Koch, H.; Lücker, S.; Nowka, B.; Richter, A.; Spieck, E.; Lebedeva, E. NxrB encoding the beta subunit of nitrite oxidoreductase as functional and phylogenetic marker for nitrite-oxidizing Nitrospira: Functional and phylogenetic marker for Nitrospira. Environ. Microbiol. 2014, 16, 3055-3071. [CrossRef] [PubMed]

18. Levy-Booth, D.J.; Prescott, C.E.; Grayston, S.J. Microbial functional genes involved in nitrogen fixation, nitrification and denitrification in forest ecosystems. Soil Biol. Biochem. 2014, 75, 11-25. [CrossRef]

19. Geisseler, D.; Horwath, W.R.; Joergensen, R.G.; Ludwig, B. Pathways of nitrogen utilization by soil microorganisms-A review. Soil Biol. Biochem. 2010, 42, 2058-2067. [CrossRef]

20. Elser, J.J.; Bracken, M.E.S.; Cleland, E.E.; Gruner, D.S.; Harpole, W.S.; Hillebrand, H.; Ngai, J.T.; Seabloom, E.W.; Shurin, J.B.; Smith, J.E. Global analysis of nitrogen and phosphorus limitation of primary producers in freshwater, marine and terrestrial ecosystems. Ecol. Lett. 2007, 10, 1135-1142. [CrossRef]

21. FAO. World Fertilizer Trends and Outlook to 2022; Summary Report; FAO: Rome, Italy, 2019.

22. Heffer, P. Assessment of Fertilizer Use by Crop at the Global Level; International Fertilizer Industry Association: Paris, France, 2013.

23. Kopiński, J. Diversification of nitrogen fertilization in Polish agriculture. Pol. J. Agric. 2018, 32, 3-16.

24. Barker, A.V.; Pilbeam, D.J. Handbook of Plant Nutrition; CRC Press: Bocca Raton, FL, USA, 2015.

25. Dyśko, J.; Kaniszewski, K.; Kowalczyk, W.; Nowak, J.; Wójcik, P. Sustainable Fertilization of Horticultural Plants. Institute of Horticulture: Skierniewice, Poland, 2014.

26. McCauley, A.; Jones, C.; Jacobsen, J. Functions and Deficiency and Toxicity Symptoms; Nutrient Management Module; Montana State University: Bozeman, MT, USA, 2009.

27. Roy, R.N.; Finck, A.; Blair, G.J.; Tandon, H.I.S. Plant Nutrition for Food Security: A Guide for Integrated Nutrient Management; FAO Fertilizer and Plant Nutrition Bulletin; FAO: Rome, Italy, 2006.

28. Wong, M. Visual symptoms of plant nutrient deficiencies in nursery and landscape plants. Soil Crop Manag. 2005, 10, 1-4.

29. Martínez-Espinosa, R.M.; Cole, J.A.; Richardson, D.J.; Watmough, N.J. Enzymology and ecology of the nitrogen cycle. Biochem. Soc. Trans. 2011, 39, 175-178. [CrossRef] [PubMed]

30. Akiyama, H.; Yan, X.; Yagi, K. Estimations of emission factors for fertilizer-induced direct $\mathrm{N}_{2} \mathrm{O}$ emissions from agricultural soils in Japan: Summary of available data. Soil Sci. Plant Nutr. 2006, 52, 774-787. [CrossRef]

31. Beaulieu, J.J.; Tank, J.L.; Hamilton, S.K.; Wollheim, W.M.; Hall, R.O.; Mulholland, P.J.; Peterson, B.J.; Ashkenas, L.R.; Cooper, L.W.; Dahm, C.N. Nitrous oxide emission from denitrification in stream and river networks. Proc. Natl. Acad. Sci. USA 2011, 108, 214-219. [CrossRef]

32. Dodds, W.; Smith, V. Nitrogen, phosphorus, and eutrophication in streams. Inland Water 2016, 6, 155-164. [CrossRef]

33. Howarth, R.W. Coastal nitrogen pollution: A review of sources and trends globally and regionally. Harmful Algae 2008, 8, 14-20. [CrossRef]

34. Johnson, P.T.J.; Townsend, A.R.; Cleveland, C.C.; Glibert, P.M.; Howarth, R.W.; McKenzie, V.J.; Rejmankova, E.; Ward, M.H. Linking environmental nutrient enrichment and disease emergence in humans and wildlife. Ecol. Appl. 2010, 20, 16-29. [CrossRef] [PubMed]

35. Blanco-Canqui, H.; Schlegel, A.J. Implications of inorganic fertilization of irrigated corn on soil properties: Lessons learned after 50 years. J. Environ. Qual. 2013, 42, 861-871. [CrossRef] [PubMed]

36. Wang, P.; Zhang, W.; Li, M.; Han, Y. Does fertilizer education program increase the technical efficiency of chemical fertilizer use? Evidence from wheat production in China. Sustainability 2019, 11, 543. [CrossRef]

37. Han, S.; Zeng, L.; Luo, X.; Xiong, X.; Wen, S.; Wang, B.; Chen, W.; Huang, Q. Shifts in Nitrobacter-and Nitrospira-like Nitriteoxidizing bacterial communities under long-term fertilization practices. Soil Biol. Biochem. 2018, 124, 118-125. [CrossRef]

38. Li, J.H.; Yang, Y.J.; Li, B.W.; Li, W.J.; Wang, G.; Knops, J.M. Effects of nitrogen and phosphorus fertilization on soil carbon fractions in Alpine Meadows on the Qinghai-Tibetan Plateau. PLoS ONE 2014, 9, e103266. [CrossRef] [PubMed]

39. Stockmann, U.; Adams, M.A.; Crawford, J.W.; Field, D.J.; Henakaarchchi, N.; Jenkins, M.; Minasny, B.; McBratney, A.B.; De Courcelles, V.d.R.; Singh, K. The knowns, known unknowns and unknowns of sequestration of soil organic carbon. Agric. Ecosyst. Environ. 2013, 164, 80-99. [CrossRef]

40. Xiang, X.; He, D.; He, J.-S.; Myrold, D.D.; Chu, H. Ammonia-oxidizing bacteria rather than archaea respond to short-term urea amendment in an Alpine Grassland. Soil Biol. Biochem. 2017, 107, 218-225. [CrossRef]

41. Zamanian, K.; Kuzyakov, Y. Contribution of soil inorganic carbon to atmospheric $\mathrm{CO}_{2}$ : More Important than previously thought. Glob. Chang. Biol. 2019, 25, E1-E3. [CrossRef]

42. Zhou, X.; Fornara, D.; Wasson, E.A.; Wang, D.; Ren, G.; Christie, P.; Jia, Z. Effects of 44 years of chronic nitrogen fertilization on the soil nitrifying community of permanent grassland. Soil Biol. Biochem. 2015, 91, 76-83. [CrossRef]

43. Allison, S.D.; Lu, Y.; Weihe, C.; Goulden, M.L.; Martiny, A.C.; Treseder, K.K.; Martiny, J.B. Microbial abundance and composition influence litter decomposition response to environmental change. Ecology 2013, 94, 714-725. [CrossRef] 
44. Coolon, J.D.; Jones, K.L.; Todd, T.C.; Blair, J.M.; Herman, M.A. Long-term nitrogen amendment alters the diversity and assemblage of soil bacterial communities in tallgrass prairie. PLOS ONE 2013, 8, e67884. [CrossRef]

45. Liao, H.; Zhang, Y.; Zuo, Q.; Du, B.; Chen, W.; Wei, D.; Huang, Q. Contrasting responses of bacterial and fungal communities to aggregate-size fractions and long-term fertilizations in soils of northeastern China. Sci. Total Environ. 2018, 635, 784-792. [CrossRef]

46. Ramirez, K.S.; Lauber, C.L.; Knight, R.; Bradford, M.A.; Fierer, N. Consistent effects of nitrogen fertilization on soil bacterial communities in contrasting systems. Ecology 2010, 91, 3463-3470. [CrossRef]

47. Hallin, S.; Jones, C.M.; Schloter, M.; Philippot, L. Relationship between N-cycling communities and ecosystem functioning in a 50-year-old fertilization experiment. ISME J. 2009, 3, 597-605. [CrossRef]

48. Wessén, E.; Nyberg, K.; Jansson, J.K.; Hallin, S. Responses of bacterial and archaeal ammonia oxidizers to soil organic and fertilizer amendments under long-term management. Appl. Ecol. 2010, 45, 193-200. [CrossRef]

49. Treseder, K.K. Nitrogen additions and microbial biomass: A meta-analysis of ecosystem studies. Ecol. Lett. 2008, 11, 1111-1120. [CrossRef] [PubMed]

50. Paungfoo-Lonhienne, C.; Yeoh, Y.K.; Kasinadhuni, N.R.P.; Lonhienne, T.G.; Robinson, N.; Hugenholtz, P.; Ragan, M.A.; Schmidt, S. Nitrogen fertilizer dose alters fungal communities in sugarcane soil and rhizosphere. Sci. Rep. 2015, 5, 1-6. [CrossRef] [PubMed]

51. Morrison, E.W.; Frey, S.D.; Sadowsky, J.J.; van Diepen, L.T.A.; Thomas, W.K.; Pringle, A. Chronic nitrogen additions fundamentally restructure the soil fungal community in a temperate forest. Fungal Ecol. 2016, 23, 48-57. [CrossRef]

52. Afreh, D.; Zhang, J.; Guan, D.; Liu, K.; Song, Z.; Zheng, C.; Deng, A.; Feng, X.; Zhang, X.; Wu, Y. Long-term fertilization on nitrogen use efficiency and greenhouse gas emissions in a double maize cropping system in subtropical China. Soil Till. Res. 2018, 180, 259-267. [CrossRef]

53. Miller, M.N.; Zebarth, B.; Dandie, C.E.; Burton, D.L.; Goyer, C.; Trevors, J.T. Crop residue influence on denitrification, n2o emissions and denitrifier community abundance in soil. Soil Biol. Biochem. 2008, 40, 2553-2562. [CrossRef]

54. Saunders, O.E.; Fortuna, A.-M.; Harrison, J.H.; Cogger, C.G.; Whitefield, E.; Green, T. Gaseous Nitrogen and bacterial responses to raw and digested dairy manure applications in incubated soil. Environ. Sci. Technol. 2012, 46, 11684-11692. [CrossRef] [PubMed]

55. Zhang, Q.-C.; Shamsi, I.H.; Xu, D.-T.; Wang, G.-H.; Lin, X.-Y.; Jilani, G.; Hussain, N.; Chaudhry, A.N. Chemical fertilizer and organic manure inputs in soil exhibit a vice versa pattern of microbial community structure. Appl. Soil Ecol. 2012, 57, 1-8. [CrossRef]

56. Xiang, X.; Liu, J.; Zhang, J.; Li, D.; Xu, C.; Kuzyakov, Y. Divergence in fungal abundance and community structure between soils under long-term mineral and organic fertilization. Soil Till. Res. 2020, 196, 104491. [CrossRef]

57. Bandyopadhyay, K.K.; Misra, A.K.; Ghosh, P.K.; Hati, K.M.; Mandal, K.G.; Moahnty, M. Effect of irrigation and nitrogen application methods on input use efficiency of wheat under limited water supply in a vertisol of central India. Irrig. Sci. 2010, 28, 285-299. [CrossRef]

58. Herencia, J.F.; Garcia-Galavis, P.A.; Maqueda, C. Long-term effect of organic and mineral fertilization on soil physical properties under greenhouse and outdoor management practices. Pedosphere 2011, 21, 443-453. [CrossRef]

59. Šimon, T. The Influence of long-term organic and mineral fertilization on soil organic matter. Soil Water Res. 2008, 3, 41-51. [CrossRef]

60. Fließbach, A.; Oberholzer, H.-R.; Gunst, L.; Mäder, P. Soil organic matter and biological soil quality indicators after 21 years of organic and conventional farming. Agric. Ecosyst. Environ. 2007, 118, 273-284. [CrossRef]

61. Bradley, D.; Christodoulou, M.; Caspari, C.; Di Luca, P. Integrated Crop Management Systems in the EU; Amended Final Report for European Commission DG Environment; Agra CEAS Consulting: Ashford, UK, 2002.

62. Department of Agriculture and Rural Development. Regulation of the Minister of Agriculture and Rural Development in Poland on Integrated Agricultural Production of 16 December 2010 (Official Journal 2010, No. 256, Item 1722); Department of Agriculture and Rural Development: Warsaw, Poland, 2010.

63. European Parliament and of the Council. Regulation (EU) 2019/1009 of the European Parliament and of the Council of 5 June 2019. Laying down Rules on the Making Available on the Market of EU Fertilising Products; European Parliament and of the Council: Strasbourg, France, 2019.

64. Sejm and Senate Complex of Poland. Fertilizer and Fertilization Act of 10 July 2007 in Poland (Official Journal 2007, No. 147, Item 1033); Sejm and Senate Complex of Poland: Warsaw, Poland, 2007.

65. Delgado, J.; Lemunyon, J. Nutrient management. In Encyclopedia of Soil Science; Lal, R., Ed.; Marcel Decker: New York, NY, USA, 2006; pp. 1157-1160.

66. Prasad, R.; Hochmuth, G.J.; Boote, K.J. Estimation of nitrogen pools in irrigated potato production on sandy soil using the model SUBSTOR. PLOS ONE 2015, 10, e0117891. [CrossRef]

67. Shober, A.L.; Hochmuth, G.; Wiese, C. An Overview of Nutrient Budgets for Use in Nutrient Management Planning; University of Florida: Gainesville, FL, USA, 2011.

68. Cissé, L. Balanced fertilization for sustainable use of plant nutrients. In Fertilizer Best Management Practices; International Fertilizer Industry Association: Paris, France, 2007; pp. 33-46.

69. Bhatt, B.; Chandra, R.; Ram, S.; Pareek, N. Long-term effects of fertilization and manuring on productivity and soil biological properties under rice (Oryza sativa)-wheat (Triticum aestivum) sequence in mollisols. Arch. Agron. Soil Sci. 2016, 62, 1109-1122. [CrossRef] 
70. Eo, J.; Park, K.-C. Long-term effects of imbalanced fertilization on the composition and diversity of soil bacterial community. Agric. Ecosyst. Environ. 2016, 231, 176-182. [CrossRef]

71. Blumenthal, J.; Baltensperger, D.D.; Cassman, K.G.; Mason, S.; Pavlista, A. Importance and effect of nitrogen on crop quality and health. In Nitrogen in the Environment; Hatfield, J.L., Follett, R.F., Eds.; Academic Press: Cambridge, MA, USA, 2008 ; pp. 51-70.

72. D'Amico-Damião, V.; Nunes, H.D.; Couto, P.A.; Lemos, L.B. Straw type and nitrogen fertilization influence winter common bean yield and quality. Int. J. Plant Prod. 2020, 14, 703-712. [CrossRef]

73. Pikuła, D. Effect of long-term straw fertilization on plant yield and soil fertility. Stud. Rep. 2015, 45, 85-96.

74. Crohn, D. Nitrogen mineralization and its importance in organic waste recycling. In Proceedings of the National Alfalfa Symposium, San Diego, CA, USA, 13-15 December 2004; pp. 13-15.

75. Bailey, K.L.; Lazarovits, G. Suppressing soil-borne diseases with residue management and organic amendments. Soil Till. Res. 2003, 72, 169-180. [CrossRef]

76. Libudzisz, Z.; Kowal, K.; Żakowska, Z. Technical Microbiology. Microorganisms and Their Environment; Scientific Publisher PWN: Warsaw, Poland, 2007.

77. Vranova, V.; Rejsek, K.; Formanek, P. Proteolytic activity in soil: A review. Appl. Soil Ecol. 2013, 70, 23-32. [CrossRef]

78. Rahman, R.; Basri, M.; Salleh, A.B. Thermostable alkaline protease from Bacillus stearothermophilus f1-Nutritional factors affecting protease production. Ann. Microbiol. 2003, 53, 199-210.

79. Ayyasamy, P.M.; Chun, S.; Lee, S. Desorption and dissolution of heavy metals from contaminated soil using Shewanella sp.(HN-41) Amended with various carbon sources and synthetic soil organic matters. J. Hazard. Mater. 2009, 161, 1095-1102. [CrossRef]

80. Bijak, M.; Ponczek, M.B.; Nowak, P. Serine proteases and their classification according to the merops system. Kosmos 2015, 64, 31-45.

81. Burchacka, E.; Witkowska, D. Serine proteases and their function in the pathogenesis of bacterial infections. Adv. Hyg. Exp. Med. 2016, 70, 678-694.

82. Rudenskaya, G.N.; Pupov, D.V. Cysteine proteinases of microorganisms and viruses. Biochemistry 2008, 73, 1-13. [CrossRef]

83. Wenig, K.; Chatwell, L.; von Pawel-Rammingen, U.; Bjorck, L.; Huber, R.; Sondermann, P. Structure of the Streptococcal endopeptidase IdeS, a cysteine proteinase with strict specificity for IgG. Proc. Natl. Acad. Sci. USA 2004, 101, 17371-17376. [CrossRef] [PubMed]

84. Yegin, S.; Fernandez-Lahore, M.; Salgado, A.J.G.; Guvenc, U.; Goksungur, Y.; Tari, C. Aspartic proteinases from Mucor spp. in cheese manufacturing. Appl. Microbiol. Biotechnol. 2011, 89, 949-960. [CrossRef] [PubMed]

85. Gradišar, H.; Friedrich, J.; Križaj, I.; Jerala, R. Similarities and specificities of fungal keratinolytic proteases: Comparison of keratinases of Paecilomyces marquandii and Doratomyces microsporus to some known proteases. Appl. Environ. Microbiol. 2005, 71, 3420-3426. [CrossRef]

86. Sumantha, A.; Larroche, C.; Pandey, A. Microbiology and industrial biotechnology of food-grade proteases: A perspective. Food Technol. Biotechnol. 2006, 44, 211.

87. Allison, S.D.; Vitousek, P.M. Responses of extracellular enzymes to simple and complex nutrient inputs. Soil Biol. Biochem. 2005, 37, 937-944. [CrossRef]

88. Dong, S.; Brooks, D.; Jones, M.D.; Grayston, S.J. A Method for linking in situ activities of hydrolytic enzymes to associated organisms in forest soils. Soil Biol. Biochem. 2007, 39, 2414-2419. [CrossRef]

89. Grandy, A.S.; Neff, J.C.; Weintraub, M.N. Carbon structure and enzyme activities in alpine and forest ecosystems. Soil Biol. Biochem. 2007, 39, 2701-2711. [CrossRef]

90. Fuka, M.M.; Engel, M.; Hagn, A.; Munch, J.C.; Sommer, M.; Schloter, M. Changes of diversity pattern of proteolytic bacteria over time and space in an agricultural soil. Microb. Ecol. 2009, 57, 391-401. [CrossRef] [PubMed]

91. Fuka, M.M.; Engel, M.; Gattinger, A.; Bausenwein, U.; Sommer, M.; Munch, J.C.; Schloter, M. Factors influencing variability of proteolytic genes and activities in arable soils. Soil Biol. Biochem. 2008, 40, 1646-1653. [CrossRef]

92. Näsholm, T.; Kielland, K.; Ganeteg, U. Uptake of organic nitrogen by plants: Tansley review. New Phytol. 2009, 182, 31-48. [CrossRef]

93. Brzostek, E.R.; Finzi, A.C. Substrate supply, fine roots, and temperature control proteolytic enzyme activity in temperate forest soils. Ecology 2011, 92, 892-902. [CrossRef]

94. Landi, L.; Renella, G.; Giagnoni, L.; Nannipieri, P. Activities of Proteolytic Enzymes. In Methods of Soil Enzymology; Dick, R.P., Ed.; Soil Science Society of America: Madison, WI, USA, 2015; pp. 247-260.

95. Gardini, F.; Martuscelli, M.; Caruso, M.C.; Galgano, F.; Crudele, M.A.; Favati, F.; Guerzoni, M.E.; Suzzi, G. Effects of pH, temperature and $\mathrm{NaCl}$ concentration on the growth kinetics, proteolytic activity and biogenic amine production of Enterococcus faecalis. Int. J. Food Microbiol. 2001, 64, 105-117. [CrossRef]

96. Bach, H.-J.; Munch, J.C. Identification of bacterial sources of soil peptidases. Biol. Fertil. Soils 2000, 31, 219-224. [CrossRef]

97. Marx, M.-C.; Kandeler, E.; Wood, M.; Wermbter, N.; Jarvis, S.C. Exploring the enzymatic landscape: Distribution and kinetics of hydrolytic enzymes in soil particle-size fractions. Soil Biol. Biochem. 2005, 37, 35-48. [CrossRef]

98. Niewiadomska, A.; Sulewska, H.; Wolna-Maruwka, A.; Klama, J. Effect of organic fertilization on development of proteolytic bacteria and activity of proteases in the soil for cultivation of maize (Zea mays L.). Arc. Environ. Prot. 2010, 36, 47-56.

99. Nitu, T.T.; Milu, U.M.; Jahangir, M.M.R. Cover Crops and Soil Nitrogen Cycling. In Cover Crops and Sustainable Agriculture; Islam, R., Sherman, B., Eds.; CRC Press: Boca Raton, FL, USA, 2021; pp. 209-226. 
100. Nannipieri, P.; Kandeler, E.; Ruggiero, P. Enzyme activities and microbiological and biochemical processes in soil. In Enzymes in the Environment: Activity, Ecology and Applications; Burns, R.G., Dick, R.P., Eds.; Marcel Dekker: New York, NY, USA, 2002; pp. $1-33$.

101. Wyczółkowski, A.; Dąbek-Szreniawska, M. Enzymes involved in the mineralization of organic nitrogen. Acta Agrophys. 2005, 3, 37-61.

102. Schloter, M.; Nannipieri, P.; Sørensen, S.J.; van Elsas, J.D. Microbial indicators for soil quality. Biol Fertil Soils 2018, 54, 1-10. [CrossRef]

103. Alur, M.D. Metabolic pathways, nitrogen metabolism. In Metabolic Pathways, Nitrogen Metabolism; Robison, R., Batt, C.A., Patel, P.D., Eds.; Academic Press: Cambridge, MA, USA, 1999; pp. 1288-1298.

104. Szostak, B.; Jezierska-Tys, S.; Bekier-Jaworska, E. The intensity of the ammonification and nitrification process in soil in pig farms. Acta Agrophys. 2005, 6, 251-260.

105. Dąbek-Szreniawska, M.; Zimon, A.; Wyczółkowski, A.I. Activity of enzymes in the ammonification process in soil with the addition of nitrogenous organic substances. Acta Agroph. 2006, 8, 23-33.

106. Stefanakis, A.; Akratos, C.S.; Tsihrintzis, V.A. Treatment Processes in VFCWs. In Vertical Flow Constructed Wetlands; Stefanakis, A., Akratos, C.S., Tsihrintzis, V.A., Eds.; Elsevier: Amsterdam, The Netherlands, 2014; pp. 57-84.

107. Vymazal, J. Removal of Nutrients in Various Types of Constructed Wetlands. Sci. Total Environ. 2007, 380, 48-65. [CrossRef]

108. Vymazal, J.; Greenway, M.; Tonderski, K.; Brix, H.; Mander, Ü. Constructed wetlands for wastewater treatment. In Wetlands and Natural Resource Management; Verhoeven, J.T.A., Beltman, B., Bobbink, R., Whigham, D.F., Eds.; Springer: New York, NY, USA, 2006; pp. 69-96.

109. Saeed, T.; Sun, G. A Review on nitrogen and organics removal mechanisms in subsurface flow constructed wetlands: Dependency on environmental parameters, operating conditions and supporting media. J. Environ. Manag. 2012, 112, 429-448. [CrossRef]

110. Fujii, K.; Yamada, T.; Hayakawa, C.; Nakanishi, A.; Funakawa, S. Decoupling of protein depolymerization and ammonification in nitrogen mineralization of acidic forest soils. Appl. Soil Ecol. 2020, 153, 103572. [CrossRef]

111. Yevdokimov, I.V.; Saha, S.; Blagodatsky, S.A.; Kudeyarov, V.N. Nitrogen immobilization by soil microorganisms depending on nitrogen application rates. Eur. Soil Sci. 2005, 38, 516-523.

112. Bottomley, P.; Taylor, A.E.; Myrold, D.D. A Consideration of the relative contributions of different microbial subpopulations to the soil n cycle. Front. Microbiol. 2012, 3, 373. [CrossRef] [PubMed]

113. Li, X.; He, H.; Zhang, X.; Kazanci, C.; Li, Z.; Necpalova, M.; Ma, Q. Calculation of fungal and bacterial inorganic nitrogen immobilization rates in soil. Soil Biol. Biochem. 2021, 153, 108114. [CrossRef]

114. Myrold, D.D.; Posavatz, N.R. Potential importance of bacteria and fungi in nitrate assimilation in soil. Soil Biol. Biochem. 2007, 39, 1737-1743. [CrossRef]

115. Grzyb, A.; Wolna-Maruwka, A.; Niewiadomska, A. Environmental factors affecting the mineralization of crop residues. Agronomy 2020, 10, 1951. [CrossRef]

116. Grzebisz, W. Plant Production: A Textbook for School Students Educating in the Profession of a Farmer Technician: Collective Work; Environment and Basics of Agrotechnics; Hortpress: Warsaw, Poland, 2008.

117. Chen, B.; Liu, E.; Tian, Q.; Yan, C.; Zhang, Y. Soil nitrogen dynamics and crop residues. A review. Agron. Sustain. Dev. 2014, 34, 429-442. [CrossRef]

118. Zandt, D.; Fritz, C.; Wichern, F. In the Land of Plenty: Catch crops trigger nitrogen uptake by soil microorganisms. Plant Soil 2018, 423, 549-562. [CrossRef]

119. Montaño, N.M.; García-Oliva, F.; Jaramillo, V.J. Dissolved organic carbon affects soil microbial activity and nitrogen dynamics in a mexican tropical deciduous Forest. Plant Soil 2007, 295, 265-277. [CrossRef]

120. Dail, D.B.; Davidson, E.A.; Chorover, J. Rapid abiotic transformation of nitrate in an acid forest soil. Biogeochemistry 2001, 54, 131-146. [CrossRef]

121. Myrold, D.D.; Bottomley, P.J. Nitrogen mineralization and immobilization. In Agronomy Monographs; Schepers, J.S., Raun, W.R., Eds.; American Society of Agronomy, Crop Science Society of America, Soil Science Society of America: Madison, WI, USA, 2015; pp. $157-172$.

122. Olk, D.C.; Cassman, K.G.; Schmidt-Rohr, K.; Anders, M.M.; Mao, J.-D.; Deenik, J.L. Chemical stabilization of soil organic nitrogen by phenolic lignin residues in anaerobic agroecosystems. Soil Biol. Biochem. 2006, 38, 3303-3312. [CrossRef]

123. Coskun, D.; Britto, D.T.; Shi, W.; Kronzucker, H.J. Nitrogen transformations in modern agriculture and the role of biological nitrification inhibition. Nat. Plants 2017, 3, 17074. [CrossRef] [PubMed]

124. Norton, J.M.; Alzerreca, J.J.; Suwa, Y.; Klotz, M.G. Diversity of ammonia monooxygenase operon in autotrophic ammoniaoxidizing bacteria. Arch. Microbiol. 2002, 177, 139-149. [CrossRef] [PubMed]

125. Phillips, C.J.; Harris, D.; Dollhopf, S.L.; Gross, K.L.; Prosser, J.I.; Paul, E.A. Effects of agronomic treatments on structure and function of ammonia-oxidizing communities. Appl. Environ. Microbiol. 2000, 66, 5410-5418. [CrossRef] [PubMed]

126. Könneke, M.; Bernhard, A.E.; de la Torre, J.R.; Walker, C.B.; Waterbury, J.B.; Stahl, D.A. Isolation of an autotrophic ammoniaoxidizing marine archaeon. Nature 2005, 437, 543-546. [CrossRef] [PubMed]

127. Soliman, M.; Eldyasti, A. Ammonia-oxidizing bacteria (AOB) opportunities and applications: A review. Rev Environ. Sci. Biotechnol. 2018, 17, 285-321. [CrossRef] 
128. Avrahami, S.; Liesack, W.; Conrad, R. Effects of temperature and fertilizer on activity and community structure of soil ammonia oxidizers. Environ. Microbiol. 2003, 5, 691-705. [CrossRef]

129. Kowalchuk, G.A.; Stephen, J.R. Ammonia-Oxidizing Bacteria: A model for molecular microbial ecology. Annu. Rev. Microbiol. 2001, 55, 485-529. [CrossRef]

130. De Boer, W.; Kowalchuk, G.A. Nitrification in acid soils: Microorganisms and mechanisms. Soil Biol. Biochem. 2001, 33, 853-866. [CrossRef]

131. Nicol, G.W.; Leininger, S.; Schleper, C.; Prosser, J.I. The influence of soil pH on the diversity, abundance and transcriptional activity of ammonia oxidizing archaea and bacteria. Environ. Microbiol. 2008, 10, 2966-2978. [CrossRef]

132. Morimoto, S.; Hayatsu, M.; Takada Hoshino, Y.; Nagaoka, K.; Yamazaki, M.; Karasawa, T.; Takenaka, M.; Akiyama, H. Quantitative analyses of ammonia-oxidizing archaea (aoa) and ammonia-oxidizing bacteria (AOB) in fields with different soil types. Microb. Environ. 2011, 26, 248-253. [CrossRef]

133. Enwall, K.; Philippot, L.; Hallin, S. Activity and composition of the denitrifying bacterial community respond differently to long-term fertilization. Appl. Environ. Microbiol. 2005, 71, 8335-8343. [CrossRef]

134. Bernhard, A. The nitrogen cycle: Processes, players, and human impact. Nat. Educ. Knowl. 2010, 3, 25.

135. Lücker, S.; Nowka, B.; Rattei, T.; Spieck, E.; Daims, H. The genome of Nitrospina gracilis illuminates the metabolism and evolution of the major marine nitrite oxidizer. Front. Microbiol. 2013, 4, 27. [CrossRef]

136. Sorokin, D.Y.; Lücker, S.; Vejmelkova, D.; Kostrikina, N.A.; Kleerebezem, R.; Rijpstra, W.I.C.; Damsté, J.S.S.; Le Paslier, D.; Muyzer, G.; Wagner, M. Nitrification expanded: Discovery, physiology and genomics of a nitrite-oxidizing bacterium from the phylum Chloroflexi. ISME J. 2012, 6, 2245-2256. [CrossRef]

137. Daims, H.; Lücker, S.; Wagner, M. A new perspective on microbes formerly known as nitrite-oxidizing bacteria. Trends Microbiol. 2016, 24, 699-712. [CrossRef]

138. Ferguson, S.J.; Richardson, D.J.; van Spanning, R.J.M. Biochemistry and molecular biology of nitrification. In Biology of the Nitrogen Cycle; Bothe, H., Ferguson, S., Newton, W.E., Eds.; Elsevier: Amsterdam, The Netherlands, 2007; pp. $209-222$.

139. Fiencke, C.; Spieck, E.; Bock, E. Nitrifying bacteria. In Nitrogen Fixation in Agriculture, Forestry, Ecology, and the Environment; Werner, D., Newton, W.E., Eds.; Springer: Heidelberg, Germany, 2005; pp. 255-276.

140. Ward, B.B. Nitrification. In Encyclopedia of Ecology; Jørgensen, S.E., Fath, B.D., Eds.; Elsevier: Amsterdam, The Netherlands, 2013; pp. 351-358.

141. Millar, N.; Robertson, G.P. Nitrogen transfers and transformations in row-crop ecosystems. In The Ecology of Agricultural Ecosystems: Long-Term Research on the Path to Sustainability; Hampilton, S., Doll, J.E., Robertson, P., Eds.; Oxford University Press: New York, NY, USA, 2015; pp. 213-225.

142. Zhu, X.; Burger, M.; Doane, T.A.; Horwath, W.R. Ammonia oxidation pathways and nitrifier denitrification are significant sources of $\mathrm{N}_{2} \mathrm{O}$ and $\mathrm{NO}$ under low oxygen availability. Proc. Natl. Acad. Sci. USA 2013, 110, 6328-6333. [CrossRef]

143. Schulze, E.-D.; Mooney, H.A. Biodiversity and Ecosystem Function; Springer: Berlin/Heidelberg, Germany, 2002.

144. Beeckman, F.; Motte, H.; Beeckman, T. Nitrification in agricultural soils: Impact, actors and mitigation. Curr. Opin. Biotechnol. 2018, 50, 166-173. [CrossRef]

145. Akhtar, M.; Hussain, F.; Ashraf, M.Y.; Qureshi, T.M.; Akhter, J.; Awan, A.R. Influence of Salinity on Nitrogen Transformations in Soil. Commun. Soil Sci. Plant Anal. 2012, 43, 1674-1683. [CrossRef]

146. Podlaska, B.; Russel, S. Characteristics of nitrifying bacteria and their role in the nitrogen cycle. In Interdisciplinary Issues in Engineering and Environmental Protection; Traczewska, T.M., Kaźmierczak, B., Eds.; Publishing House of the Wrocław University of Technology: Wrocław, Poland, 2003; pp. 263-279.

147. Viotti, P.; Collivignarelli, M.C.; Martorelli, E.; Raboni, M. Oxygen control and improved denitrification efficiency by dosing ferrous ions in the anoxic reactor. Desalin. Water Treat. 2016, 57, 18240-18247. [CrossRef]

148. Butterbach-Bahl, K.; Baggs, E.M.; Dannenmann, M.; Kiese, R.; Zechmeister-Boltenstern, S. Nitrous Oxide emissions from soils: How well do we understand the processes and their controls? Philos. Trans. R. Soc. B. 2013, 368, 20130122. [CrossRef] [PubMed]

149. Kloos, K.; Mergel, A.; Rösch, C.; Bothe, H. Denitrification within the genus Azospirillum and other associative bacteria. Funct. Plant Biol. 2001, 28, 991-998. [CrossRef]

150. Su, F.; Takaya, N.; Shoun, H. Nitrous oxide-forming codenitrification catalyzed by cytochrome P450nor. Biosci. Biotechnol. Biochem. 2004, 68, 473-475. [CrossRef] [PubMed]

151. Matsuzaka, E.; Nomura, N.; Maseda, H.; Otagaki, H.; Nakajima-Kambe, T.; Nakahara, T.; Uchiyama, H. Participation of nitrite reductase in conversion of $\mathrm{NO}_{2}{ }^{-}$to $\mathrm{NO}_{3}{ }^{-}$in a heterotrophic nitrifier, Burkholderia cepacia $\mathrm{NH}-17$, with denitrification activity. Microb. Environ. 2003, 18, 203-209. [CrossRef]

152. Okada, N.; Nomura, N.; Nakajima-Kambe, T.; Uchiyama, H. Characterization of the aerobic denitrification in Mesorhizobium sp. strain NH-14 in comparison with that in related Rhizobia. Microb. Environ. 2005, 20, 208-215. [CrossRef]

153. Dilfuza, E. Role of microorganisms in nitrogen cycling in soils. In Soil Nutrients; Minarsari, M., Ed.; Nova Science Publishers Inc.: Hauppauge, NJ, USA, 2011; pp. 159-176.

154. Fuka, M.M.; Braker, S.H.G.; Philippot, L. Molecular tools to assess the diversity and density of denitrifying bacteria in their habitats. In Biology of the Nitrogen Cycle; Bothe, H., Ferguson, S., Newton, W.E., Eds.; Elsevier: Amsterdam, The Netherlands, 2007; pp. 313-330. 
155. Rana, A.; Pandey, R.K.; Ramakrishnan, B. Enzymology of the nitrogen cycle and bioremediation of toxic nitrogenous compounds. In Smart Bioremediation Technologies; Bhatt, P., Ed.; Elsevier: Amsterdam, The Netherlands, 2019; pp. 45-61.

156. Laughlin, R.J.; Stevens, R.J. Evidence for fungal dominance of denitrification and codenitrification in a grassland soil. Soil Sci. Soc. Am. J. 2002, 66, 1540-1548. [CrossRef]

157. McLain, J.E.; Martens, D.A. $\mathrm{N}_{2} \mathrm{O}$ production by heterotrophic $\mathrm{n}$ transformations in a semiarid soil. Appl. Soil Ecol. 2006, 32, 253-263. [CrossRef]

158. Shoun, H. Denitrification and anaerobic energy producing mechanisms by fungi. Tanpakushitsu Kakusan Koso 2006, 51, 419-429.

159. Cabello, P.; Roldan, M.D.; Moreno-Vivian, C. Nitrate reduction and the nitrogen cycle in archaea. Microbiology 2004, 150, 3527-3546. [CrossRef]

160. Philippot, L. Denitrifying genes in bacterial and archaeal genomes. BBA Gene Struct. Expr. 2002, 1577, 355-376. [CrossRef]

161. Stremińska, M.A.; Błaszczyk, M. The biogeochemical cycle of nitrogen in soils of coniferous forest ecosystems. Post. Mikrobiol. 2004, 43, 235-250.

162. Gaillard, R.; Duval, B.D.; Osterholz, W.R.; Kucharik, C.J. Simulated effects of soil texture on nitrous oxide emission factors from corn and soybean agroecosystems in Wisconsin. J. Environ. Qual. 2016, 45, 1540-1548. [CrossRef] [PubMed]

163. Payne, E.G.; Fletcher, T.D.; Cook, P.L.; Deletic, A.; Hatt, B.E. Processes and drivers of nitrogen removal in stormwater biofiltration. Crit. Rev. Environ. Sci. Technol. 2014, 44, 796-846. [CrossRef]

164. Zhang, S.; Liu, F.; Xiao, R.; Li, Y.; He, Y.; Wu, J. Effects of vegetation on ammonium removal and nitrous oxide emissions from pilot-scale drainage ditches. Aquat. Bot. 2016, 130, 37-44. [CrossRef]

165. Clough, T.J.; Lanigan, G.J.; de Klein, C.A.M.; Samad, M.S.; Morales, S.E.; Rex, D.; Bakken, L.R.; Johns, C.; Condron, L.M.; Grant, J. Influence of soil moisture on codenitrification fluxes from a urea-affected pasture soil. Sci Rep 2017, 7, 2185. [CrossRef]

166. Spott, O.; Russow, R.; Stange, C.F. Formation of hybrid $\mathrm{N}_{2} \mathrm{O}$ and hybrid $\mathrm{N}_{2}$ due to codenitrification: First review of a barely considered process of microbially mediated N-nitrosation. Soil Biol. Biochem. 2011, 43, 1995-2011. [CrossRef]

167. Long, A.; Heitman, J.; Tobias, C.; Philips, R.; Song, B. Co-occurring anammox, denitrification, and codenitrification in agricultural soils. Appl. Environ. Microbiol. 2013, 79, 168-176. [CrossRef]

168. Strous, M.; Fuerst, J.A.; Kramer, E.H.M.; Logemann, S.; Muyzer, G.; van de Pas-Schoonen, K.T.; Webb, R.; Kuenen, J.G.; Jetten, M.S.M. Missing lithotroph identified as new Planctomycete. Nature 1999, 400, 446-449. [CrossRef]

169. Kartal, B.; Kuypers, M.M.M.; Lavik, G.; Schalk, J.; Op den Camp, H.J.; Jetten, M.S.M.; Strous, M. Anammox bacteria disguised as denitrifiers: Nitrate reduction to dinitrogen gas via nitrite and ammonium. Environ. Microbiol. 2007, 9, 635-642. [CrossRef]

170. Ali, M.; Oshiki, M.; Awata, T.; Isobe, K.; Kimura, Z.; Yoshikawa, H.; Hira, D.; Kindaichi, T.; Satoh, H.; Fujii, T. Physiological characterization of anaerobic ammonium oxidizing bacterium 'Candidatus J Ettenia Caeni'. Environ. Microbiol. 2015, 17, 2172-2189. [CrossRef]

171. Oshiki, M.; Shinyako-Hata, K.; Satoh, H.; Okabe, S. Draft genome sequence of an anaerobic ammonium-oxidizing bacterium 'Candidatus Brocadia Sinica'. Genome Announc. 2015, 3, e00267-15. [CrossRef]

172. Strous, M.; Pelletier, E.; Mangenot, S.; Rattei, T.; Lehner, A.; Taylor, M.W.; Horn, M.; Daims, H.; Bartol-Mavel, D.; Wincker, P. Deciphering the evolution and metabolism of an anammox bacterium from a community genome. Nature 2006, 440, 790-794. [CrossRef]

173. Kuenen, J.G. Anammox bacteria: From discovery to application. Nat. Rev. Microbiol. 2008, 6, 320-326. [CrossRef]

174. van Niftrik, L.; Geerts, W.J.; van Donselaar, E.G.; Humbel, B.M.; Webb, R.I.; Fuerst, J.A.; Verkleij, A.J.; Jetten, M.S.; Strous, M. Linking ultrastructure and function in four genera of anaerobic ammonium-oxidizing bacteria: Cell plan, glycogen storage, and localization of cytochrome c proteins. J. Bacteriol. 2008, 190, 708-717. [CrossRef] [PubMed]

175. Han, P.; Gu, J.-D. More refined diversity of anammox bacteria recovered and distribution in different ecosystems. Appl. Microbiol. Biotechnol. 2013, 97, 3653-3663. [CrossRef] [PubMed]

176. Schmid, M.C.; Maas, B.; Dapena, A.; van de Pas-Schoonen, K.; van de Vossenberg, J.; Kartal, B.; van Niftrik, L.; Schmidt, I.; Cirpus, I.; Kuenen, J.G. biomarkers for in situ detection of anaerobic ammonium-oxidizing (anammox) bacteria. Appl. Environ. Microbiol. 2005, 71, 1677-1684. [CrossRef] [PubMed]

177. van Teeseling, M.C.F.; Mesman, R.J.; Kuru, E.; Espaillat, A.; Cava, F.; Brun, Y.V.; Van Nieuwenhze, M.S.; Kartal, B.; van Niftrik, L. Anammox planctomycetes have a peptidoglycan cell wall. Nat Commun. 2015, 6, 6878. [CrossRef]

178. Jetten, M.S.; van Niftrik, L.; Strous, M.; Kartal, B.; Keltjens, J.T.; Op den Camp, H.J. Biochemistry and molecular biology of anammox bacteria. Crit. Rev. Biochem. Mol. Biol. 2009, 44, 65-84. [CrossRef]

179. Byrne, N.; Strous, M.; Crépeau, V.; Kartal, B.; Birrien, J.-L.; Schmid, M.; Lesongeur, F.; Schouten, S.; Jaeschke, A.; Jetten, M. Presence and activity of anaerobic ammonium-oxidizing bacteria at deep-sea hydrothermal vents. ISME J. 2009, 3, 117-123. [CrossRef]

180. Jaeschke, A.; Op den Camp, H.J.; Harhangi, H.; Klimiuk, A.; Hopmans, E.C.; Jetten, M.S.; Schouten, S.; Sinninghe Damsté, J.S. 16S rRNA gene and lipid biomarker evidence for anaerobic ammonium-oxidizing bacteria (anammox) in California and Nevada Hot Springs. FEMS Microbiol. Ecol. 2009, 67, 343-350. [CrossRef]

181. Jin, R.-C.; Yang, G.-F.; Yu, J.-J.; Zheng, P. The Inhibition of the anammox process: A review. Chem. Eng. 2012, 197, 67-79. [CrossRef]

182. Tang, C.; Zheng, P.; Mahmood, Q.; Chen, J. Effect of substrate concentration on stability of anammox biofilm reactors. J. Cent. South Univ. Technol. 2010, 17, 79-84. [CrossRef] 
183. Zhu, G.; Xia, C.; Shanyun, W.; Zhou, L.; Liu, L.; Zhao, S. Occurrence, activity and contribution of anammox in some freshwater extreme environments. Environ. Microbiol. Rep. 2015, 7, 961-969. [CrossRef]

184. Gao, D.-W.; Tao, Y. Versatility and application of anaerobic ammonium-oxidizing bacteria. Appl. Microbiol. Biotechnol. 2011, 91, 887-894. [CrossRef]

185. Pereira, A.D.; Cabezas, A.; Etchebehere, C.; de Chernicharo, C.A.L.; de Araújo, J.C. Microbial communities in anammox reactors: A review. Environ. Technol. Rev. 2017, 6, 74-93. [CrossRef]

186. Tomaszewski, M.; Cema, G.; Ziembińska-Buczyńska, A. Influence of temperature and pH on the anammox process: A review and meta-analysis. Chemosphere 2017, 182, 203-214. [CrossRef] [PubMed]

187. Jaroszynski, L.W.; Cicek, N.; Sparling, R.; Oleszkiewicz, J.A. Impact of free ammonia on anammox rates (anoxic ammonium oxidation) in a moving bed biofilm reactor. Chemosphere 2012, 88, 188-195. [CrossRef] [PubMed]

188. Jung, J.Y.; Kang, S.H.; Chung, Y.C.; Ahn, D.H. Factors affecting the activity of anammox bacteria during start up in the continuous culture reactor. Water Sci. Technol. 2007, 55, 459-468. [CrossRef] [PubMed]

189. Jaroszynski, L.W.; Cicek, N.; Sparling, R.; Oleszkiewicz, J.A. Importance of the operating pH in maintaining the stability of anoxic ammonium oxidation (anammox) activity in moving bed biofilm reactors. Bioresour. Technol. 2011, 102, 7051-7056. [CrossRef]

190. Dapena-Mora, A.; Fernández, I.; Campos, J.L.; Mosquera-Corral, A.; Méndez, R.; Jetten, M.S.M. Evaluation of activity and inhibition effects on anammox process by batch tests based on the nitrogen gas production. Enzym. Microb. Technol. 2007, 40, 859-865. [CrossRef]

191. Hu, B.; Rush, D.; van der Biezen, E.; Zheng, P.; van Mullekom, M.; Schouten, S.; Sinninghe Damsté, J.S.; Smolders, A.J.P.; Jetten, M.S.M.; Kartal, B. New Anaerobic, ammonium-oxidizing community enriched from peat soil. Appl. Environ. Microbiol. 2011, 77, 966-971. [CrossRef] [PubMed]

192. Coolen, M.J.; Abbas, B.; Van Bleijswijk, J.; Hopmans, E.C.; Kuypers, M.M.; Wakeham, S.G.; Sinninghe Damsté, J.S. Putative ammonia-oxidizing crenarchaeota in suboxic waters of the Black Sea: A basin-wide ecological study using $16 \mathrm{~S}$ ribosomal and functional genes and membrane lipids. Environ. Microbiol. 2007, 9, 1001-1016. [CrossRef]

193. Penton, C.R.; Devol, A.H.; Tiedje, J.M. Molecular evidence for the broad distribution of anaerobic ammonium-oxidizing bacteria in freshwater and marine sediments. Appl. Environ. Microbiol. 2006, 72, 6829-6832. [CrossRef] [PubMed]

194. Schubert, C.J.; Durisch-Kaiser, E.; Wehrli, B.; Thamdrup, B.; Lam, P.; Kuypers, M.M. Anaerobic ammonium oxidation in a tropical freshwater system (Lake Tanganyika). Environ. Microbiol. 2006, 8, 1857-1863. [CrossRef]

195. Humbert, S.; Tarnawski, S.; Fromin, N.; Mallet, M.-P.; Aragno, M.; Zopfi, J. Molecular detection of anammox bacteria in terrestrial ecosystems: Distribution and diversity. ISME J. 2010, 4, 450-454. [CrossRef] [PubMed]

196. Raymond, J.; Siefert, J.L.; Staples, C.R.; Blankenship, R.E. The natural history of nitrogen fixation. Mol. Biol. Evol. 2004, 21, 541-554. [CrossRef]

197. Herridge, D.F.; Peoples, M.B.; Boddey, R.M. Global inputs of biological nitrogen fixation in agricultural systems. Plant Soil 2008, 311, 1-18. [CrossRef]

198. Łyszcz, M.; Gałazka, A. The process of biological fixation of atmospheric nitrogen. In Habitat and Agrotechnical Conditions of Plant Production in Poland; Studies and Reports IUNG-PIB; Institute of Soil Science and Plant Cultivation, National Research Institute: Puławy, Poland, 2016; pp. 59-70.

199. Cheng, Q. Perspectives in biological nitrogen fixation research. J. Integr. Plant Biol. 2008, 50, 786-798. [CrossRef]

200. Król, M.J. A Azospirillum-Associative Free Nitrogen-Fixing Bacteria; Institute of Soil Science and Plant Cultivation, National Research Institute: Puławy, Poland, 2006.

201. Natywa, M.; Selwet, M.; Ambroży, K.; Pociejowska, M. Effect of nitrogen fertilization and irrigation on the number of Azotobacter bacteria in the soil under maize cultivation at various stages of plant development. Pol. J. Agric. 2013, 14, 53-58.

202. Peters, J.W.; Boyd, E.S.; Hamilton, T.L.; Rubio, L.M. Biochemistry of Mo-nitrogenase. In Nitrogen Cycling in Bacteria: Molecular Analysis; Moir, J.W.B., Ed.; Caister Academic Press: Norfolk, UK, 2011; pp. 59-99.

203. Rees, D.C.; Akif Tezcan, F.; Haynes, C.A.; Walton, M.Y.; Andrade, S.; Einsle, O.; Howard, J.B. Structural basis of biological nitrogen fixation. Philos. Trans. R. Soc. A 2005, 363, 971-984. [CrossRef] [PubMed]

204. Siemann, S.; Schneider, K.; Dröttboom, M.; Müller, A. The Fe-only nitrogenase and the Mo nitrogenase from Rhodobacter capsulatus. Eur. J. Biochem. 2002, 269, 1650-1661. [CrossRef]

205. Wielbo, J.; Skorupska, A. Evolution of the symbiotic system of Rhizobium-legumes. Post. Mikrobiol. 2003, 42, $263-283$.

206. Mus, F.; Alleman, A.B.; Pence, N.; Seefeldt, L.C.; Peters, J.W. Exploring the alternatives of biological nitrogen fixation. Metallomics 2018, 10, 523-538. [CrossRef] [PubMed]

207. Nordult, S.; Ureta, A. Evidence for conformational protection of nitrogenase in Gluconacetobacter diazotrophicus. J. Bacteriol. 2002, 184, 5805-5809.

208. Egamberdieva, D.; Kucharova, Z. Cropping effects on microbial population and nitrogenase activity in saline arid soil. Turk. J. Biol. 2008, 32, 85-90.

209. Vitousek, P.M.; Cassman, K.; Cleveland, C.; Crews, T.; Field, C.B.; Grimm, N.B.; Howarth, R.W.; Marino, R.; Martinelli, L.; Rastetter, E.B. Towards an ecological understanding of biological nitrogen fixation. In The Nitrogen Cycle at Regional to Global Scales; Boyer, E.W., Howarth, R.W., Eds.; Springer: Dordrecht, The Netherlands, 2002; pp. 1-45. 
210. Niewiadomska, A.; Sulewska, H.; Wolna-Maruwka, A.; Ratajczak, K.; Głuchowska, K.; Waraczewska, Z.; Budka, A. An assessment of the influence of co-inoculation with endophytic bacteria and rhizobia, and the influence of PRP SOL and PRP EBV fertilisers on the microbial parameters of soil and nitrogenase activity in yellow lupine (Lupinus luteus L.) cultivation. Pol. J. Environ. Stud. 2018, 27, 2687-2702. [CrossRef]

211. Liu, Y.; Wu, L.; Baddeley, J.A.; Watson, C.A. Models of biological nitrogen fixation of legumes. A review. Agron. Sust. Dev. 2011, 31, 155-172. [CrossRef]

212. Long, S.R. Genes and signals in the Rhizobium-legume symbiosis. Plant Physiol. 2001, 125, 69-72. [CrossRef]

213. Salvagiotti, F.; Cassman, K.G.; Specht, J.E.; Walters, D.T.; Weiss, A.; Dobermann, A. Nitrogen uptake, fixation and response to fertilizer $\mathrm{n}$ in soybeans: A review. Field Crop. Res. 2008, 108, 1-13. [CrossRef]

214. Sellstedt, A.; Richau, K.H. Aspects of nitrogen-fixing Actinobacteria in particular free-living and symbiotic Frankia. FEMS Microbiol. Lett. 2013, 342, 179-186. [CrossRef] [PubMed]

215. Van Nguyen, T.; Pawlowski, K. Frankia and actinorhizal plants: Symbiotic nitrogen fixation. In Rhizotrophs: Plant Growth Promotion to Bioremediation; Mehanz, S., Ed.; Springer: Singapore, 2017; pp. 237-261.

216. Fauvart, M.; Michiels, J. Rhizobial secreted proteins as determinants of host specificity in the Rhizobium-legume symbiosis. FEMS Microbiol. Lett. 2008, 285, 1-9. [CrossRef] [PubMed]

217. Mus, F.; Crook, M.B.; Garcia, K.; Garcia Costas, A.; Geddes, B.A.; Kouri, E.D.; Paramasivan, P.; Ryu, M.-H.; Oldroyd, G.E.D.; Poole, P.S. Symbiotic nitrogen fixation and the challenges to its extension to nonlegumes. Appl. Environ. Microbiol. 2016, 82, 3698-3710. [CrossRef] [PubMed]

218. Oldroyd, G.E.; Downie, J.A. Coordinating nodule morphogenesis with rhizobial infection in legumes. Annu. Rev. Plant Biol. 2008, 59, 519-546. [CrossRef] [PubMed]

219. Radutoiu, S.; Madsen, L.H.; Madsen, E.B.; Jurkiewicz, A.; Fukai, E.; Quistgaard, E.M.; Albrektsen, A.S.; James, E.K.; Thirup, S.; Stougaard, J. LysM domains mediate lipochitin-oligosaccharide recognition and nfr genes extend the symbiotic host range. EMBO J. 2007, 26, 3923-3935. [CrossRef] [PubMed]

220. Sprent, J.I.; James, E.K. Legume evolution: Where do nodules and mycorrhizas fit in? Plant Physiol. 2007, 144, 575-581. [CrossRef]

221. Boivin, S.; Fonouni-Farde, C.; Frugier, F. How auxin and cytokinin phytohormones modulate root microbe interactions. Front. Plant Sci. 2016, 7, 1240. [CrossRef]

222. Verma, R.; Annapragada, H.; Katiyar, N.; Shrutika, N.; Das, K.; Murugesan, S. Rhizobium. In Beneficial Microbes in Agro-Ecology; Amaresan, N., Annapurna, K., Kumar, K., Eds.; Elsevier: Amsterdam, The Netherlands, 2020; pp. 37-54.

223. Chandra, S.; Choure, K.; Dubey, R.C.; Maheshwari, D.K. Rhizosphere competent Mesorhizobium loti MP6 induces root hair curling, inhibits Sclerotinia sclerotiorum and enhances growth of indian mustard (Brassica campestris). Braz. J. Microbiol. 2007, 38, 124-130. [CrossRef]

224. Tamiru, G.; Muleta, D. The effect of rhizobia isolates against black root rot disease of faba bean (Vicia faba L.) caused by Fusarium solani. Open Agric. J. 2018, 12, 131-147. [CrossRef]

225. Shaukat, S.S.; Siddiqui, I.A. The influence of mineral and carbon sources on biological control of charcoal rot fungus, Macrophomina phaseolina by fluorescent Pseudomonas in tomato. Lett. Appl. Microbiol. 2003, 36, 392-398. [CrossRef] [PubMed]

226. Król, M.J.; Zielewicz-Dukowska, J. Genetic aspects of $\mathrm{N}_{2}$ binding of Azospirillum bacteria. Post. Mikrobiol 2005, $44,47-56$.

227. Martyniuk, S. The importance of the biological process of atmospheric nitrogen fixation in ecological agriculture. J. Res. Appl. Agric. Eng. 2008, 53, 9-14.

228. Svistoonoff, S.; Hocher, V.; Gherbi, H. Actinorhizal root nodule symbioses: What is signalling telling on the origins of nodulation? Curr. Opin. Plant Biol. 2014, 20, 11-18. [CrossRef] [PubMed]

229. Abrol, Y.P.; Raghuram, N.; Sachdev, M.S. Agricultural Nitrogen Use and Its Environmental Implications; IK International Pvt Ltd: New Dehli, India, 2007.

230. Meisinger, J.J.; Jokela, W.E. Mmonia Volatilization from Dairy and Poultry Manure: Managing Nutrients and Pathogens from Animal Agriculture; NRAES-130; Natural Resource, Agriculture, and Engineering Service: Ithaca, NY, USA, 2000; pp. 334-354.

231. Jones, K.M.; Kobayashi, H.; Davies, B.W.; Taga, M.E.; Walker, G.C. How rhizobial symbionts invade plants: The SinorhizobiumMedicago model. Nat. Rev. Microbiol. 2007, 5, 619-633. [CrossRef]

232. Sommer, S.G.; Hutchings, N.J. Ammonia emission from field applied manure and its reduction-Invited paper. Eur. J. Agron. 2001, 15, 1-15. [CrossRef]

233. Yang, J.; Jiao, Y.; Yang, W.Z.; Gu, P.; Bai, S.G.; Liu, L.J. Review of methods for determination of ammonia volatilization in farmland. In Proceedings of the IOP Conference Series: Earth and Environmental Science; IOP Publishing: Bristol, UK, 2018 ; Volume 113.

234. Zhou, W.; Tian, Y.H.; Cao, Y.S.; Yin, B. A comparative study on two methods for determination of ammonia volatilization. Acta Pedofil. Sin. 2011, 48, 1090-1095.

235. Ghaly, A.E.; Ramakrishnan, V.V. Nitrogen sources and cycling in the ecosystem and its role in air, water and soil pollution: A critical review. J. Pollut. Eff. Control 2015, 3, 1-26.

236. Randall, G.W.; Vetsch, J.A.; Huffman, J.R. Corn production on a subsurface-drained mollisol as affected by time of nitrogen application and nitrapyrin. Agron. J. 2003, 95, 1213-1219. [CrossRef]

237. Bolan, N.S.; Hedley, M.J. Role of Carbon, Nitrogen, and Sulfur Cycles in Soil Acidification. In Handbook of Soil Acidity; Rengel, Z., Ed.; Marcel Dekker Inc.: New York, NY, USA, 2003; pp. 29-56. 
238. Davis, R.L.; Patton, J.J.; Teal, R.K.; Tang, Y.; Humphreys, M.T.; Mosali, J.; Girma, K.; Lawles, J.W.; Moges, S.M.; Malapati, A. Nitrogen balance in the magruder plots following 109 years in continuous winter wheat. J. Plant Nutr. 2003, 26, 1561-1580. [CrossRef]

239. Ascott, M.J.; Gooddy, D.C.; Wang, L.; Stuart, M.E.; Lewis, M.A.; Ward, R.S.; Binley, A.M. Global patterns of nitrate storage in the vadose zone. Nat. Commun. 2017, 8, 1-7. [CrossRef] [PubMed]

240. Cardenas, L.M.; Cuttle, S.P.; Crabtree, B.; Hopkins, A.; Shepherd, A.; Scholefield, D.; Del Prado, A. Cost effectiveness of nitrate leaching mitigation measures for grassland livestock systems at locations in England and Wales. Sci. Total Environ. 2011, 409, 1104-1115. [CrossRef]

241. Delgado, J.A.; Shaffer, M.J.; Lal, H.; McKinney, S.P.; Gross, C.M.; Cover, H. Assessment of nitrogen losses to the environment with a nitrogen trading tool (NTT). Comput. Electron. Agric. 2008, 63, 193-206. [CrossRef]

242. Wang, M.; Pendall, E.; Fang, C.; Li, B.; Nie, M. A global perspective on agroecosystem nitrogen cycles after returning crop residue. Agric. Ecosyst. Environ. 2018, 266, 49-54. [CrossRef]

243. Roberts, T.; Kirkpatrick, W.; County, D.; Slaton, N.; Norman, R. Estimating Nutrient Removal for Row Crops Grown in Arkansas; Agriculture and Natural Resources; University of Arkansas Cooperative Extension Service Printing Services: Fayetteville, AR, USA, 2015.

244. FAO. World Fertilizer Trends and Outlook to 2020; Summary Report; FAO: Rome, Italy, 2017. 